\title{
Singapore vs. the 'Singapore of Africa'-Different Approaches to Managing Urban Agriculture
}

\author{
Ada Górna * (D) and Krzysztof Górny (D) \\ Faculty of Geography and Regional Studies, University of Warsaw, 00-927 Warsaw, Poland; \\ krzysztofgorny@uw.edu.pl \\ * Correspondence: ada.gorna@uw.edu.pl
}

Citation: Górna, A.; Górny, K. Singapore vs. the 'Singapore of Africa'-Different Approaches to Managing Urban Agriculture. Land 2021, 10, 987. https://doi.org/ $10.3390 /$ land10090987

Academic Editors: Przemysław Śleszyński, Maciej J. Nowak and Giancarlo Cotella

Received: 10 July 2021

Accepted: 15 September 2021

Published: 18 September 2021

Publisher's Note: MDPI stays neutral with regard to jurisdictional claims in published maps and institutional affiliations.

Copyright: (c) 2021 by the authors. Licensee MDPI, Basel, Switzerland. This article is an open access article distributed under the terms and conditions of the Creative Commons Attribution (CC BY) license (https:// creativecommons.org/licenses/by/ $4.0 /)$.

\begin{abstract}
Through structured comparison, this article seeks to present the different approaches to urban agriculture in the cities of Singapore and Kigali. The former is seen as a model 'smart city' worth following worldwide, while the latter is frequently referred to as the 'Singapore of Africa'. The research conducted was divided into two stages. The first one was desk-based and included the analysis of satellite and aerial images along with the analysis of legal documents regarding land ownership and urban agriculture management. The second one was based on field work carried out in 2019 in both cities and comprised the mapping of areas encompassed by urban agriculture, the collection of photographic documentation, field observations, as well as semi-structured interviews. The research was summarized in line with a comparative analysis of institutional and legal framework of urban agriculture and policy towards its development; spatial features of urban agriculture, including distribution, location, and area; as well as inherent features of urban agriculture, including systems of production, main crops, production methods, and functions. The process makes it clear that despite the fact that urban agriculture is considered in planning documents of both cities, the scale of the activity and the approach towards it differ markedly. In Singapore, the authorities support mainly the high-technology and land-efficient solutions, with other, low-profit forms of agricultural activity being pushed out from the urban space. In turn, in Kigali, where the scale of agricultural activity is incomparably greater, the inhabitants enjoy a certain freedom to make use of unused land in cultivation, which increases their food security and enhances their ability to cope with external stresses.
\end{abstract}

Keywords: urban agriculture; Kigali; Singapore; land-use policy; urban development

\section{Introduction}

The work underpinning this article entailed a systematic comparison of the urban agriculture in the cities of Singapore and Kigali. Rwanda is one of the most dynamically developing African countries, with its capital Kigali being increasingly referred to as the 'Singapore of Africa'. The use of the term, most common in media discourse [1-5], results from the rapid economic growth and ease of doing business as well as the introduction of modern urban policies similar to those implemented in Singapore. As urban agriculture constitutes an important element of Kigali's urban tissue, it becomes valid to compare the follower and the precursor also in this aspect of urban life, which is more frequently discussed with regard to sustainable and smart development as well as urban resilience (see, for instance, [6-11]). The examples analyzed allow an assessment of the future prospects for urban agriculture in different economies, and different sociocultural and political contexts. Does the approach to managing urban agriculture in Kigali mirror that in Singapore? Are the patterns of urban agriculture development similar? In order to answer these questions, one should characterize and confront the policies toward urban agriculture in both cities. In the paper, we point to differences and similarities between Kigali and Singapore from the point of view of how the institutional and legal framework shapes the distribution and 
inherent features of urban agriculture, as set in the natural, socioeconomic and political context. Such a framework is particularly important, given the general direction and rate of development of urban agriculture as well as the determining of its place and significance for the urban system. Beyond that, based on qualitative methods and an exploratory approach, the article determines the main features of urban agriculture in the two cities with regard to the methods and organization of production and distribution processes. The identified set of features in question also helps present how different forms of urban agriculture develop in Kigali and Singapore. The comparative analysis comprised the following:

- Institutional and legal framework of urban agriculture and policy toward its development, including land ownership and land use policy, institutions governing urban agriculture, and planning documents;

- Spatial features, including distribution and location, and area (total, mean, minimum, maximum);

- Inherent features, including systems of production (animal and/or plant), main crops, production methods, and functions.

Thus far, the scientific literature has not offered a presentation of this kind, even if the two cities have indeed been the frequent topic of discussion from the point of view of Kigali aspiring to become 'the Singapore of Africa'.

Though far apart in terms of their economic development, the two cities are linked by issues of geography, history and politics. For a start, Singapore and Kigali are at almost identical distances from the Equator, albeit in two different directions. This means that a very humid tropical climate holds sway in both (even if Singapore is more under a maritime influence, while Kigali is affected by altitude). Under the circumstances, similar conditions for the development of plants are present, mainly in terms of precipitation, high temperatures and length of the growing season (agricultural activity is possible yearround). Singapore and Rwanda are also relatively small-the former is a microstate and a city-state, while the latter is one of Continental Africa's smallest countries. Beyond these considerations, both states are constitutional republics governed in a similar fashion, on the basis of a unitary system with a dominant parliamentary party, while the whole economic system in each is founded upon the free-market economy, albeit one in which the state enjoys a strong position. Finally, the politics of both states are making use of 'smart' solutions at present.

Concepts such as smart city, resilient city or soft city that, albeit in different ways, stress the urgency for in-depth change of the prevailing paradigm of urban development, have gained in importance not only in the two cities selected, but also worldwide.

The term smart city was born in the 1990s, when the concept was linked with the incorporation of new information and communications technology (ICT) into urban infrastructure [12]. Currently, this kind of technocratic approach is criticized to the extent that modern technological solutions are no longer treated as the concept's central element [12-14]. Therefore, today, 'smart' is taken to denote a city that draws benefit from high technology, as it seeks to raise the level of sustainability, and improve living conditions for inhabitants, as well as the quality of the natural environment, while also generating better economic prospects [13]. Key emphasis is also placed on support for communitybuilding among urban inhabitants, as well as investment in human and social capital [12]. The relevant literature thus mentions six characteristics of smart cities, i.e., a smart economy, smart mobility, smart governance, smart environment, smart living and smart people [13]. D. Maye [14] in an article linking smart city planning and urban food systems (which also include urban agriculture), came up with the term 'smart food city'. The author notes that 'smart food city' modes of governance assume consideration to be given both to modern technologies and innovative methods of food production being deployed in the city as well as to social and civil forms of innovation, in line with the traditions of the urban food system. On the other hand, the resilient city concept refers to the ability of a city system, understood in environmental, economic, social and human terms, to cope with stresses and 
disturbances $[15,16]$. Although the term is rooted in ecological studies, it is considered a complex and multidisciplinary phenomenon [16]. Not only is a resilient city able to mitigate and adapt to effects of climate change, but it is also one with less social inequalities, a fairer distribution of resources and inclusive decision-making processes. Finally, the soft city concept assumes improving the quality of life of residents and building sustainable and resilient communities not through development based on modern technologies, but on simple, low-cost, low-tech and human-centered solutions that increase urban densities and multifunctionality [17].

Urban agriculture, which constitutes the subject matter of this article, might serve as a solution to tackle many of the problems faced by modern cities, such as social inequalities, uneven and unfair distribution of food or even air pollution, and has increasingly been taken up by scientists, planners and city decisionmakers. The production of food within urban areas is considered to have many benefits for both the inhabitants and the whole urban system. When managed well, urban agriculture provides for the sustainable use of urban resources, increases the share of city space that is greenspace, improves living conditions for inhabitants and ensures the shortening of certain value and supply chains, bringing tangible economic profit [18-21]. It is also an important livelihood strategy in times of crisis and serves to maintain the adaptive capacities of cities [11]. Due to the benefits resulting from its integration within urban systems, it is often linked with the concept of sustainable development $[7,8,20,22]$, and it also complies with assumptions where the smart, resilient and soft city concepts are concerned. The role of local food production in increasing urban resilience and sustainability in Asian and African cities has been analyzed by other authors, e.g., in Ilorin (Nigeria) [23], Tamale (Ghana) [24], and Ho Chi Minh City (Vietnam) [25]. J. Padgham et al. [26] provided a multi-stressor analysis of urban and peri-urban agriculture in nine cities of the two continents, namely the following: Addis Ababa (Ethiopia); Chennai (India) Dakar (Senegal); Dar es Salaam (Tanzania); Dhaka (Bangladesh); Ibadan (Nigeria); Kampala (Uganda); Kathmandu (Nepal); and Tamale (Ghana).

Urban agriculture, however, is not arbitrarily advantageous. Poorly managed, it can lead to irreversible damage to the natural environment and pose a threat to the health of the inhabitants [27-29]. In order to maximize the positive effects of urban agriculture, it is necessary to include it in spatial planning and a long-term urban development strategy [20,21]. Considering the increased competition for space in both Kigali and Singapore, integrated actions that take into account both city authorities, planners and residents can contribute to building sustainable food systems in the city while reducing the risk of exacerbation of local conflicts. The future and role of agriculture in the city space are thus often in the hands of decisionmakers in the field of urban spatial planning [21,30,31]. It is worth mentioning a number of case studies that prove how important the institutional response is for shaping the directions of urban agricultural development. In Havana, urban agriculture appeared in the city as a grassroots response to the economic crisis in the early 1990s but the rapid institutionalization of this activity had a key impact on the maintenance of urban gardens in the urban space, and even their growing role in the spatial and functional structure [32-34]. On the other hand, A. P. Bopda, and L. Awono [35], based on the research carried out in Yaoundé, indicated that despite the omnipresence of agriculture in the capital of Cameroon, the lack of institutional response is a serious barrier to the creation of effective structures of its management. In turn, G. W. Nasinyama et al. [36], using the positive example of Kampala, emphasized that the cooperation between urban farmers and municipal policymakers can be beneficial for effectively managing urban agriculture and improving the health of urban populations. Finally, Diehl, J. A et al. [37], with regard to Singapore, also discussed in this paper, highlighted the important role of state policy, especially based on a cross-agency approach, in building sustainable forms of urban agriculture.

We argue that the institutional and legal framework plays an important role in shaping the distribution of urban agriculture across the space of two cities selected. The framework is considered to comprise legal regulations in force, especially regarding land ownership 
as well as planning documents that steer directions of spatial management in cities. These reflect the policies that central and urban authorities are pursuing, conferring rights of ownership or leaseholder rights, and the drawing up of planning documents indicating those urban areas in which it is possible to engage in agricultural activity. Legal regulations also have a direct influence on the internal features of urban agriculture, such as the selection of methods and techniques of production. Therefore, authorities are in a position to shape the presence, features and role of urban agriculture in the urban system, overall. However, they can do this solely in the given natural, socioeconomic and political conditions. The spatial distribution of urban agriculture, though steered by the authorities, depends on access to such natural resources as land and water, with this being a product of natural and economic factors.

Given the above issues, it is important to stress that urban agriculture in the two cities selected takes various forms and performs different functions. What is more, its prestige as well as the scope of its preservation in the city space differs and depends on local socio-economic and political conditions. Therefore, the comparison of Singapore and Kigali, the cities of dissimilar socio-economic characteristics, is justified, as it will enable an illustration of the full spectrum of functions performed by urban agriculture and the role it plays in achieving urban sustainability and resilience. Moreover, since the adoption of smart development is emphasized by decisionmakers in both Singapore and Kigali, this article presents different approaches toward the activity that is considered to be compliant with the concept.

The structure of the text is as follows. We start with the characteristics of the materials analyzed and the methods applied. Then, there is a presentation of the results of the research conducted in the two cities chosen. First, we characterize the socio-economic and political conditions as well as the legal and institutional framework shaping the role and position of urban agriculture in the spatial and functional structure. Secondly, we present the spatial distribution and inherent features of urban agriculture in both cities selected. Summary conclusions are then offered in the last part of the paper, where also the validity of the comparison of Singapore and Kigali is verified.

\section{Materials and Methods}

The research, based mainly on qualitative methods, was carried out in two stagesfirstly, desk-based and then in-the-field. In order to present and compare the institutional and legal framework of urban agriculture and the policy toward its development, the analysis of legal documents regarding land ownership and urban agriculture management in both cities was conducted. Among the documents analyzed, the most important ones are the Singapore Master Plan 2019 and Kigali Master Plan 2013 (together with its updated version from 2020) [38-40]. They are the latest strategic planning documents that present the authorities' vision of the future of both cities and the place and role of urban agriculture in it. Then, a satellite and aerial imagery (available via Google Earth) analysis (manual and visual interpretation) was conducted in order to locate agricultural areas and urban farms in the two cities. Thanks to the high level of spatial resolution of the images provided by Google Earth, the method in question has already proved to be suitable for research on urban agriculture, where there is a diversity of plant cover [41-44]. The study area in Singapore comes within the city limits and was taken to exclude smaller islands, which are uninhabited, serve recreational functions (as is the case with Sentosa), or are industrial (like the artificial island of Jurong). In contrast, in Kigali, where the administrative limits encompass extensive rural-type areas and even undeveloped heights, the research area was deliberately limited to the continuously built-up area.

The second stage involved fieldwork carried out in January and February 2019 in Singapore, as well as in July 2019 in Kigali. It entailed the mapping of areas encompassed by urban agriculture and the collection of photographic documentation as well as semistructured interviews (described in more detail below). Field observations represent a very important element of the work done in this case, taking in particular farms and agricultural 
areas, and their surroundings. As a result, it becomes possible to determine the features specific to places in which urban agriculture in the two cities is located.

In Singapore, semi-structured interviews based around a list of topics prepared in advance were held with representatives of 18 city farms, including either owners or employees. Due to a possibility (built into the method of research) for new subject-matter to be introduced by either the respondent or the researcher, comprehensive information on the operations of different farms was obtained and augmented by matters relating to the problems and challenges faced by actors in Singaporean urban agriculture. What is more, via the internet, an interview was also held with the Executive Manager of the Food Supply Resilience Group coming under the Agri-Food \& Veterinary Authority of Singapore.

On account of the universality of urban agriculture in Kigali's urban space as well as difficulties with identifying those responsible for particular plots, it was decided to resign from semi-structured interviews with producers. An interview was, however, held with a representative of the Kigali City Hall responsible for implementing Kigali's 2013 Master Plan. The talk held allowed for a broader perspective on the role urban agriculture plays in the city's spatial and functional structure as well as policy directions in line with prospects for development.

In Singapore, the detailed research took place in 36 urban farms. Semi-structured interviews were run in 18 of these, while in the remainder, the work was confined to field observation and the gathering of photographic documentation. In turn, where Kigali was concerned, some 98 areas occupied by urban agriculture were analyzed in the course of the fieldwork.

\section{Results}

Research material obtained during the work in Singapore and Kigali was compiled, and then subjected to the comparative analysis, which is presented in the following part of this article.

\subsection{Singapore-City of the Future}

In international smart city rankings, Singapore has for years been presented as one of the smartest. According to the IMD Smart City Index 2019 developed by the IMD World Competitiveness Center, Singapore took first place in the ranking [45]. The Asian city-state owes this very favorable position not only to the application of modern solutions as regards ICT and the high rate of economic growth, but first and foremost to the way citizens are assured a high quality of life [46]. Nonetheless, the technocratic-style solutions introduced by the authorities of Singapore are sometimes criticized and regarded as activities directed at the consolidation of power in authoritarian governments as well as the reinforcement of a pragmatic and rather depoliticized ethos in Singaporean society [47], which is contradictory to the smart city concept.

Once independent in 1965, Singapore very quickly set off along the track of dynamic (but also sustainable) development, with matters of environmental protection thus being taken account of in the spatial planning process from the very outset. This was necessary in the aftermath of a colonial period whose legacy was an almost total lack of natural plant cover [48]. Further decades of urban greening followed, ensuring the current status of Singapore as an exemplar of a metropolis in which vegetation forms a foundation for the whole urban ecosystem [49]. Moreover, thanks to the introduction of vegetation on roofs and building walls along with broad reforms seeking to restore the original structure of the urban ecosystem (a priority i.a. taken into account in The Singapore Green Plan 2012) Singapore is regarded as a pioneer of the new 'biophilic urbanism' [50].

While the above activities can be regarded as a spectacular example of the effective implementation of the sustainable development concept, Singapore is faced with the need to achieve a greater density of built-up area, due to steady growth of the population in a very limited amount of space [51]. In spite of actions to preserve greenspace within the city, Singapore's built-up areas doubled between 1965 and 2000, at the expense of forests 
and farmland [52]. On account of the cut-throat rivalry for land, activity not efficient from the economic point of view cannot be continued within the city space. What first and foremost fell victim to built-up areas was the urban agriculture analyzed in this paper. On account of Singapore being compelled to import almost all of its food [53], local production should be a priority for today's authorities. However, as resources of land are lacking and as there is a great deal of competition for land exerted by other, more profitable forms of land use, there are many urban gardens and farms unable to remain on the market. Urban agriculture in Singapore is, thus, faced with a difficult situation engendered by an existing institutional and legal framework that necessitates the restructuring of land use for the benefit of built-up areas.

\subsubsection{Spatial Policy and Urban Agriculture Management}

Once independence was gained, power passed to the People's Action Party, which has remained in power to date. Key policy at once focused on acquiring control over the use of land, allowing for very effective steering of the economic activity-agricultural activity included-pursued within the borders of Singapore. As early as 1966, the Land Acquisition Act (LAA) did much to further facilitate the purchase of land by the state [54]. Currently, all transactions, along with those concerning land intended for cultivation, are managed by state institutions, such as the Singapore Land Authority and Urban Redevelopment Authority [54,55]. The level of state ownership of land in 1992 was $80 \%$ [56], as compared with $90 \%$ now [55]. Such wide-ranging remits in the hands of the authorities not only ensure income for the Treasury, but also allow for a very centralized system of spatial planning that is now proving to be of model importance, and therefore gaining application in the Global South, where serious development challenges are faced [54]. Moreover, the land tenure system is critical to the decision-making process regarding the spatial distribution of agricultural activity within the city limits.

In Singapore, the main institution governing urban agriculture was, until recently, the Agri-Food \& Veterinary Authority of Singapore (AVA). However, on 1 April 2019, this organization split into the Singapore Food Agency (SFA) providing 'food-related services', and the Animal \& Veterinary Service (AVS) providing 'non-food related animal, plant and wildlife management services' [57]. These institutions extend technical and technological support, as well as provide for strategic collaboration over research and development. Local farmers can avail of the services of a dedicated advisor when it comes to their introduction and testing of modern technology, as well as the development of business and receipt of funding under the Agriculture Productivity Fund (APF). Until June 2016, the permissible period of land lease for agriculture in Singapore was a maximum of 10 years, with the possibility of extension for another 10 years. This constituted a serious obstacle for the operation of Singaporean farms, which were not able to achieve financial stability in such a short time. After much contradictory information from the representatives of the authorities, the AVA's decision was announced to extend this period to 20 years. It is worth emphasizing, however, that it is the Singaporean government that decides to extend the lease agreement and has full authority in this regard. According to the documents posted on the website of the Singapore Land Authority-the institution responsible for land management- the government's policy in this regard is unambiguous. Although it is possible to extend the lease period, this practice is rarely used, and each case is considered individually [58].

The main argument for the regular review of municipal land ownership is the scarcity of land resources and the need to adapt the methods of its use to the changing needs of the Singaporean economy [58]. In the case of agriculture, the lease term can only be extended if the tenants have made substantial investments in land or real estate and their activities are essential to 'strategic national needs'. This means that farms that are not profitable enough or do not fit in with the development directions promoted by the authorities may be moved, or, if they fail to obtain land use rights elsewhere, closed. The Singapore Food Agency also offers another form of lease-short-term land lease for agriculture- 
lasting from 1 to 3 years. In this case, urban agriculture is considered a temporary activity that can hardly be regarded as strategic for urban development. In addition to the timelimited lease term, city-state authorities can also control agricultural deployment through a farm license system. Residents interested in such activities, with the right to use a given area, are required to submit a business plan to the Singapore Food Agency, which then undergoes a comprehensive assessment [59]. The above practices show that authoritarian authorities limit the freedom and decision making of Singaporeans in the shaping of urban space. The government inhibits the bottom-up initiatives of residents as long as they do not fit into the chosen policy. Short-term solutions that change urban space indeed only temporarily comply with the concept of the soft city and provide for the city space dynamic character. Nevertheless, strict control of the residents' activities limits their influence on the nature of changes taking place in the city, and the concepts of the soft city, smart city and resilient city include the participation of residents in the decision-making process. In the context of the future of urban agriculture in Singapore, a matter of importance are the provisions contained in the latest Singapore Master Plan [38]. Firstly, according to the document, agricultural activity is considered to embrace units enjoying the status of agrotechnology park, aquaculture farm, plant nursery, hydroponics farm or agricultural research/experimental station. The Master Plan therefore does not take into account the soil-based cultivation that actually dominates in the farms studied here. Secondly, in line with the document, the only areas designated for agriculture are in the Lim Chu Kang district as well as the area between Tengah and the Peng Siang River [38]. However, this is not an extensive area and does not coincide with that occupied by urban farms at the present time.

Thus, the Singaporean authorities have a number of tools to control and steer the directions of urban agriculture development. The conducted field research confirms that institutional and legal structures have a key impact on the distribution and inherent features of urban farms in the city state. Strong centralization, however, prevents grassroots initiatives and inhabitants' agency, whose individual needs are usually not taken into account in the strategies implemented by state institutions. Considering the fact that, currently in the smart city concepts, emphasis is also placed on support for communitybuilding among urban inhabitants as well as investment in human and social capital [12], Singapore should not be set as an example to follow in this area.

\subsubsection{Contemporary Urban Agriculture in Singapore} Spatial Distribution of Urban Agriculture

In the context of the present research, locations represent important carriers of information. On the one hand, a location reflects the activity of authorities within the existing institutional and legal structures as well as such external factors exerting an influence as the availability of land with particular desirable attributes, and the socioeconomic situation. On the other hand, the location influences agriculture's internal features, such as methods of production and forms of organization. It thus carries with it a series of aspects making up the broader picture where the presence of agriculture in a city is concerned. The location of 36 Singaporean urban farms analyzed in this paper is presented in Figure 1. 


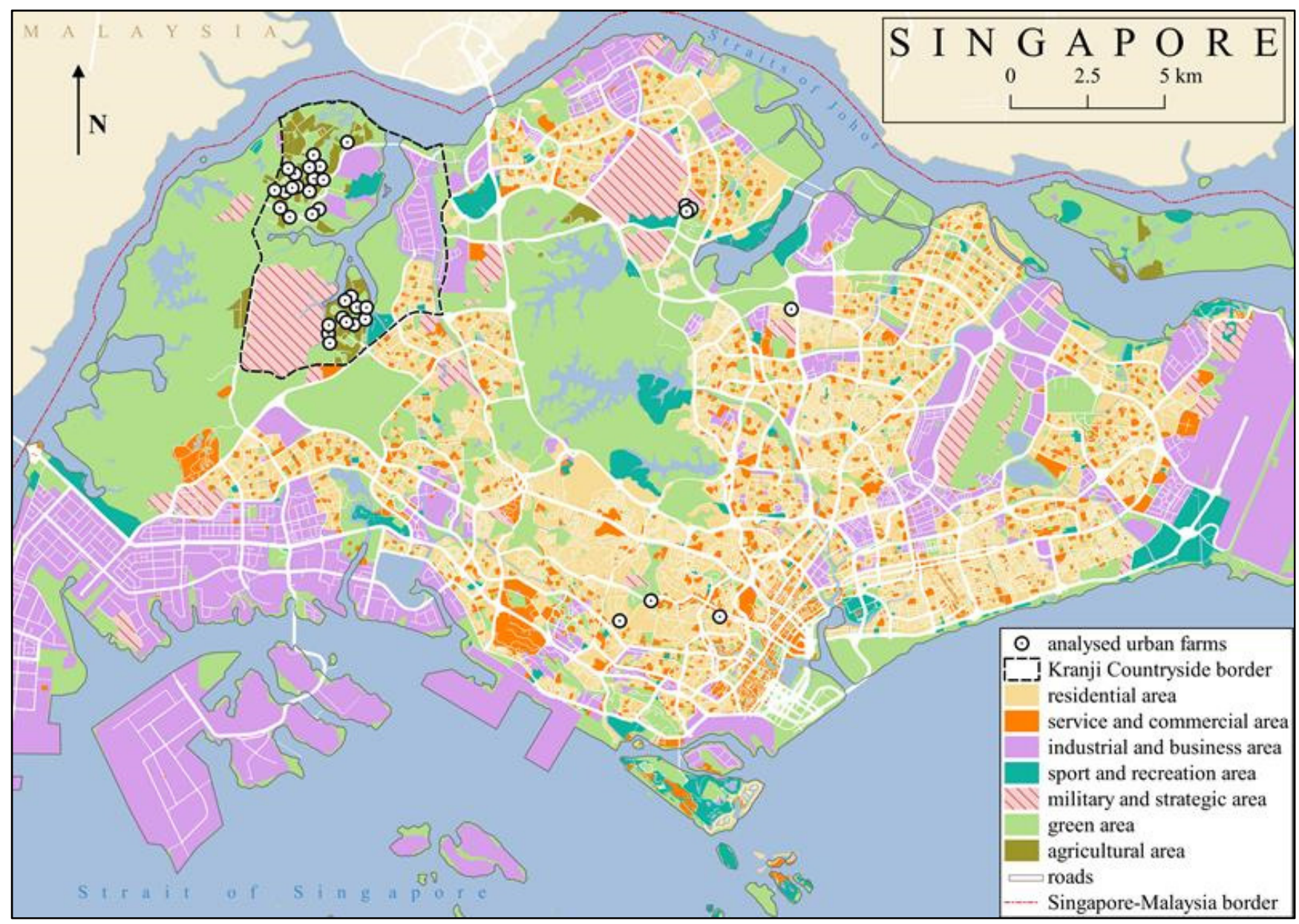

Figure 1. Land use and spatial distribution of urban farms in Singapore.

The 36 urban farms in Singapore (of total area 188.8 ha and mean area $5.24 \mathrm{ha}$ ) analyzed in this text may be categorized into two main groups. The first, comprising 28 farms of total area 178.76 ha and mean area 6.39 ha, includes the growing of plants and the raising of animals ongoing in the northwestern part of the island, named the Kranji Countryside (Figure 2). This area, in which two nature reserves (the Sungei Buloh Wetland Reserve and the Kranji Marshes) are also located, is characterized by a limited share of residential neighborhoods and is promoted as a place of recreation in the bosom of nature for Singaporeans tired of the city. However, despite the name, it is rather a stretch to consider this an area that is particularly rural in character. While it does indeed include a rather large number of urban farms, most of these exemplify 'industrial' farming, whereby cultivation and animal husbandry often take place behind walls or in greenhouses. In essence, the Kranji Countryside is a productive hinterland for Singapore located rather far from the city center. The urban farms here do produce food of both plant and animal origin, but their neighbors include defense establishments and enterprises dealing with the production of ornamental plants and pond fish. As a consequence, a specific kind of industrial and agricultural landscape is shaped here. 


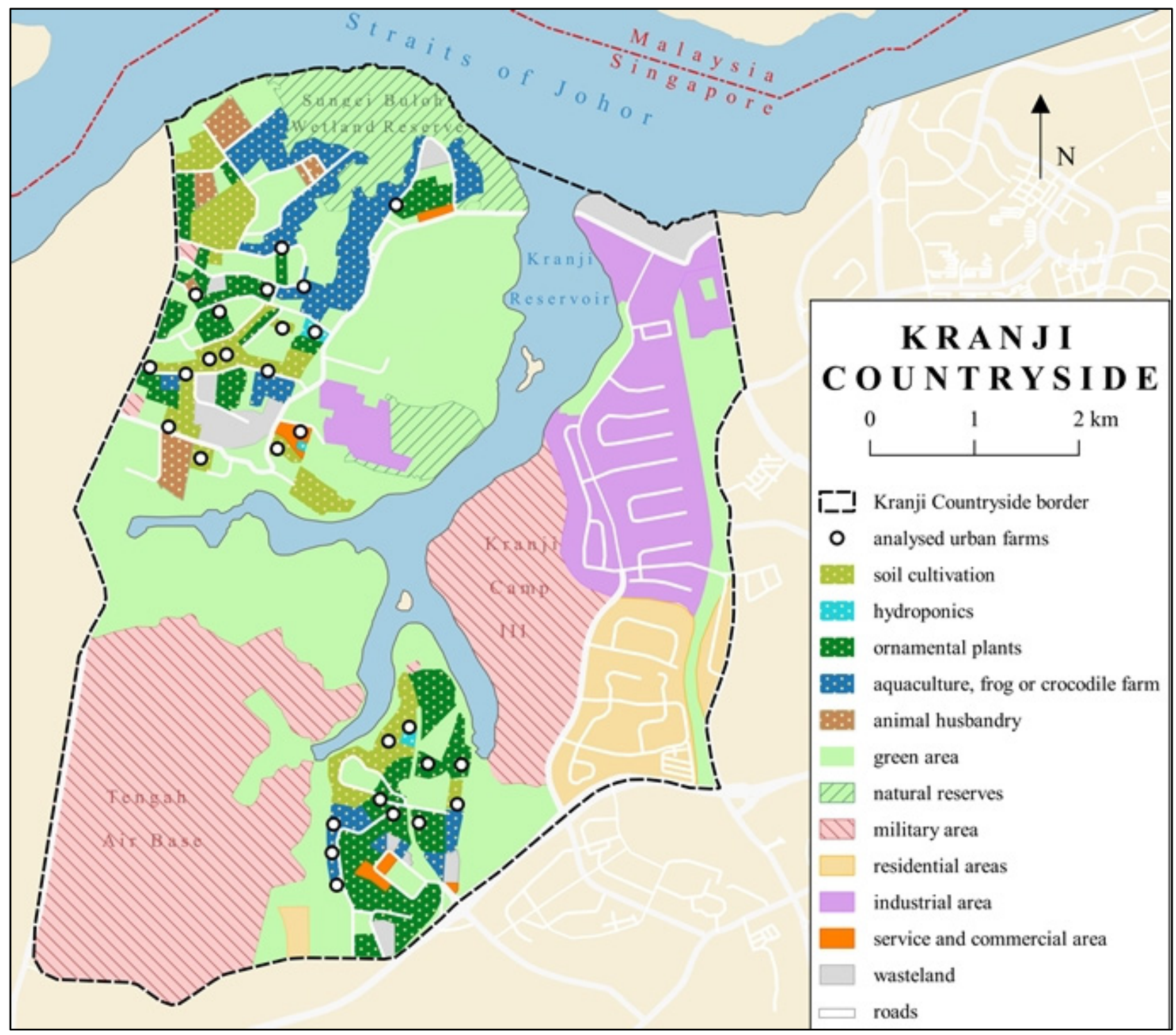

Figure 2. Land use and spatial distribution of urban farms within the Kranji Countryside.

The second group of farms in Singapore coming under study comprises eight sites of a total area of 10 ha and mean area of 1.25 ha, located in the central districts where transport links are good. Three are located in the south of the island and five in the north, on either side of the Lower Seletar Reservoir. On account of the high-density built-up area, sitting urban farms in central parts of Singapore is very much hindered and requires appropriate adaptive measures. Thus, for example, one of the farms-owned by Comcrop-is on the roof of the *SCAPE Mall, less than $200 \mathrm{~m}$ from one of Singapore's main transport arteries, Orchard Road (Figures 3 and $4 \mathrm{a}, \mathrm{b}$ ). A rooftop location denotes appropriate methods of production that revolve around soil-free hydroponics. 


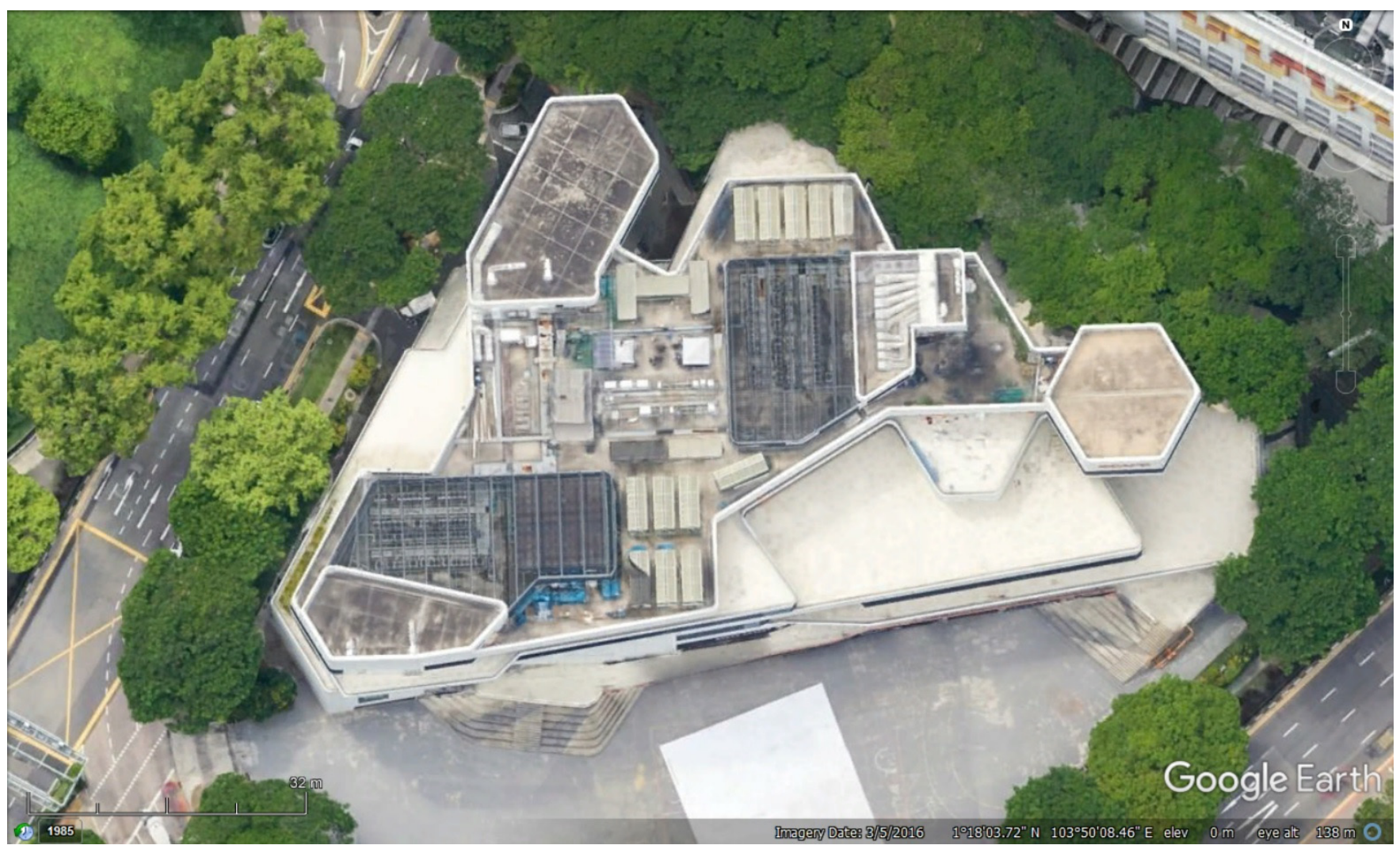

Figure 3. Satellite imagery of the Comcrop farm located on the roof of the *SCAPE building, map data: Google Earth @2016.

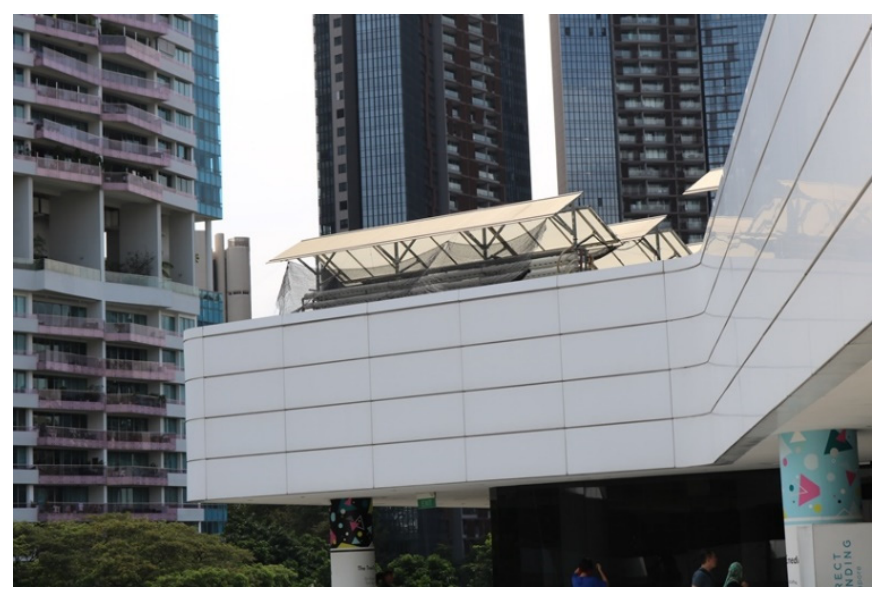

(a)

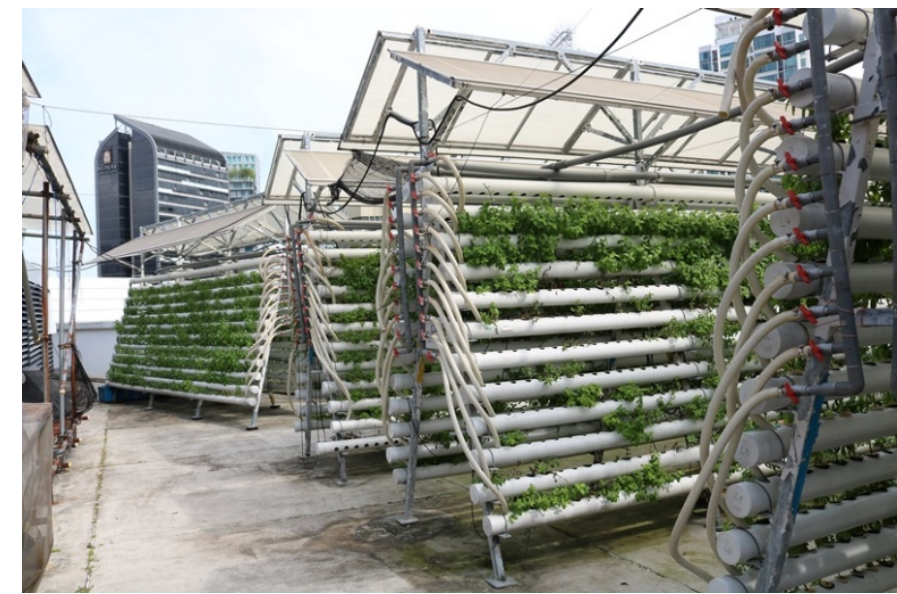

(b)

Figure 4. (a) Hydroponic modules visible from the ground floor of the *SCAPE building and (b) rows of hydroponic modules placed on the rooftop.

In the second case, the owners of the firm Citizen Farm, which is located in the Queenstown district of southern Singapore, noted the ever-greater density of construction in their area, assumed that they might need to move sooner or later, and therefore decided on the use of port containers in plant production. Thanks to that decision, the farm is, indeed, almost completely mobile and thus, ready for its probable transfer elsewhere. Limited space and current land-use policy therefore have an impact on the application of innovative solutions in the field of urban agriculture in Singapore. Ability to adapt to changing economic conditions is in line with the concepts of smart, resilient and soft cities. 
Nevertheless, the need to change locations emerged as one of the key challenges facing many individual farms, and hence, urban agriculture in Singapore in general. During the course of interviews with farm employees and owners, seven respondents indicated that the upcoming expiration of their lease was a problem they were having to face up to, with the attendant prospects of either moving elsewhere or closure. This is mainly true of farms not producing food on an industrial scale, such as Bollywood Veggies and Onesimus Garden, as well as farms located more favorably - in the north (the Oh Chin Huat Hydroponic Farm and Green Valley Farm) or in the island's central part (Citizen Farm). The system of land management in Singapore is based mainly around a 20 year lease period, which will end in the coming years in the above cases. It will depend on the state authorities whether this period is prolonged or not. It is likely that farms not profitable enough will be moved, or, if they prove unable to acquire the right to use land elsewhere, will most probably be closed down. The situation of two analyzed farms, which had been still operating in the course of the fieldwork-Oh Chin Huat Hydroponic Farm and Onesimus Garden - was recently settled. The former was closed shortly after the fieldwork in 2019. The plot it had leased is now intended for the development of housing. The latter was most probably shut down too, as the website of the farm is no longer available. That complies with what the respondent of the farm had stated during the interview, that the farm would be closed before long.

As, in line with the Master Plan published in 2019, the area designated for agriculture is limited, the closure of other farms needs to be anticipated. Moreover, by the end of 2021, the Singaporean authorities plan to allocate significant areas within the Kranji Countryside for military purposes [60]. The sites that will have to be relocated, including the 14 farms analyzed in this paper, with a total area of 84.8 hectares, were offered 60 hectares of land adjacent to the Sungei Tengah Reserve (Figure 2). Taking into account the fact that in this study, not all farms within the Kranji Countryside were examined, the area of land proposed by the government will most likely be insufficient (the area of only the farms examined is already larger by almost $25 \mathrm{ha}$ ). The militarization of areas so far occupied by agriculture is another form of legal and administrative pressure toward urban farmers who have no possibility of any objections. Out of 36 farms researched here, only 13 (of a total area of 79.6 ha) are located in areas in which, according to the Master Plan, it is possible to engage in agricultural activity. The location of the remaining 23 farms of a total area of 109.2 ha (including 14 within the Kranji Countryside) is not consistent with the provisions of the document, and therefore, they will be relocated or closed.

Although the situation of urban farms in Singapore is difficult and volatile, the government's 2019 Master Plan includes an alternative to traditional cultivation that could become an opportunity for the development of agriculture in the city. The document promotes the adaptation to produce food of the space hitherto unused but present, inter alia on roofs, and even inside buildings [38]. In line with the work conducted by L. Y. Astee and N. T. Kishnani [61], public housing estates in Singapore are suitable to apply rooftop farming based around soil-less hydroponics, with this obviously doing much to increase the output locally. The authors estimate that, in terms of yields, such farms could satisfy approximately $31 \%$ of Singapore's vegetable needs. This is then a possible direction that the development of the urban agriculture on the island could take, while being in line with the current policy on the part of the authorities. It requires, however, extensive activities in the cooperation of state, cooperative and private entities. The potential of the development of rooftop farms was also studied in other cities, e.g., Guangzhou [62,63], Hong Kong [64,65], Malaysian George Town [66], Bologna [67] and Dhaka [68]. Y-L Su et al. [63] proved on the basis of their research that sufficient roof space is available in Guangzhou for vegetable crop self-sufficiency. This shows that investments in roof farming can be an opportunity for the development of local food production also in other cities of the world. 


\section{Features of Urban Agriculture}

The new policy of the authorities in Singapore takes the defined direction of investment in modern, intensive, income-generating agriculture, with simultaneous efficient use of limited space. The production of food is to be based around high technology, thanks to which the city is to move up to a new level of 'smartness'.

Only a few forms of agricultural activity are included in the Master Plan from 2019. Thus, in the future, the document will have a significant impact on the changes of inherent features of urban farms in Singapore. Moreover, the Singapore Food Authority and Singapore Land Authority also have a wide scope of control over farming practices within the city. Obtaining the land use rights for the purpose of agricultural production depends on the decision of these institutions. In an interview, the executive director of the Food Supply Resilience Group, an organizational unit of the AVA (former SFA), emphasized that the Singaporean government is committed to promoting highly productive and innovative commercial agriculture, based on high technology and production carried out in a controlled environment, enabling the generation of maximum profits. As such practices are approved by the government, it might be assumed that farms will be willing to implement them, in order to gain the state's support. Technologically advanced practices are, therefore, most likely to become ever more popular in Singapore. The changes are already taking place, which was proved during the fieldwork.

Among the 36 farms studied, a clear majority ( 28 farms $-77.8 \%$ ) are based exclusively around plant production. It is mainly vegetables that are grown, including so-called Asian leafy vegetables (e.g., bok choy, Chinese lettuce, butterhead lettuce, Korean lettuce) cultivated on 21 farms $(58.3 \%$ of all farms analyzed and $70 \%$ of farms specialized in plant production). The other 6 farms $(16.7 \%)$ are specialized in animal production, while 2 $(5.5 \%)$ combine crops and livestock. Among the farms in which crops are cultivated, the prevailing methods are not the modern hydroponics that the authorities promote (although this is present at 7 farms, $19.4 \%$ ), but rather, the more traditional soil-based cultivation that characterizes 14 of the places studied (38.9\%). In regard to the two cases in which the methods are present side by side, respondents (representing Orchidville, as well as the Kok Fah Technology Farm) noted that hydroponic was only a supplementary method, not proving efficient enough at present, with the soil-based output thus representing the main source of income for both. The owners of both farms, however, are ready for further investment in hydroponics as well as aquaponics (Orchidville).

Four of the farms visited (11.1\%) are also trying organoponics, which is to say cultivation in raised container beds, a production method that is widespread in Cuban cities, especially Havana [31,32,43]; Pacific Agro Farm involved in growing plants in growbags, as well as pots and other containers. Eight sites $(22.2 \%)$ are involved in the growing of ornamental plants.

Two study sites stand out from the others in the diversity of their methods of production. The first of these is Citizen Farm, which applies soil-cultivation methods, hydroponics, organoponics, aquaponics, mushroom-growing and the raising of poultry. However, as may be imagined, this wide spectrum of forms of agricultural activity is a deliberate choice based around the idea of the techniques being presented (i.a. for educational and also trial purposes). Activity here includes workshops for Singapore's inhabitants in regard to sustainable food production, as well as research pursued to further perfect the modern methods on show. The second example is that of Green Valley Farm on Bah Soon Pah Road. This area actually belongs to the AVA, hence the presence here of more than 80 separate greenhouses that individuals are able to rent. Different greenhouses thus play host to various production methods, including soil-cultivation, hydroponics, organoponics or container growing. Six of the studied farms-located in the Kranji Countryside-are engaged in aquaculture, producing both ornamental pond fish and edible fish. The Jurong Frog Farm raises American Bullfrogs (Lithobates catesbeianus), while Hay Dairies engages in goat keeping. It is worth noting that 33 analyzed farms (91.7\%) are private companies, and the food they produce is intended for sale. In the remaining three facilities, the products 
are intended solely for the community members or for the restaurant operating on the farm. In addition, 12 farms (33.3\%) also offer educational and recreational services. Taking into account the difficult financial situation of a large part of the surveyed Singaporean farms, income diversification may be an opportunity to keep them on the market. Expanding their activities to include educational or recreational events may stimulate sales and at the same time, increase the farm's revenues.

On the urban farms researched, there were 14 respondents who, upon interviewing, recalled the assistance of state institutions. In 7 cases (those of the Kok Fah Technology Farm, Orchidville, the Nippon Koi Farm, Oh Chin Huat Hydroponic Farms, Pacific Agro Farm, Green Valley Farm and Comcrop), representatives said they had been supported by the AVA. The assistance extended mainly took the form of expert opinions, as well as the testing of new technology and the quality of food produced. In turn, representatives of the remaining 7 farms noted how they were not taking advantage of support from the authorities, as that was either unnecessary or deemed too expensive. According to the representatives of both Bollywood Veggies and Onesimus Garden, the state only supports high-income farms that deploy the latest technologies.

In essence, their opinion overlaps with what was said in an interview by the manager of the Food Supply Resilience Group (AVA). Farms like Bollywood Veggies and Onesimus Garden, whose operations depend in large measure on education and social activity (and whose methods of cultivation should be regarded as traditional), do not fit in with the model of modern urban agriculture that the authorities are backing. Units of this kind must, therefore, rely on the assistance of a different kind, which is cooperation between producers within the framework of the Kranji Countryside Association. This brings together 40 operating farms, not only in the Kranji Countryside, but also in other parts of the city. The association offers a platform for the exchange of experience, technology transfers, joint promotion of local output and agritourism, and also coordinated activity, seeking to improve the performance of public transport [69]. Interviews held showed that farm owners and employees at various locations know one another and cooperate on a regular basis. Examples might be the composting of wastes from the Seng Choon Farm poultry breeders at the Onesimus Garden and Farm 85 in the Kranji Countryside. This is the way in which farms create the foundations of a sustainable and self-supplying system, limiting any loss of resources.

\subsection{Kigali-'The Singapore of Africa'}

At the other extreme, our considerations turn to Kigali, the capital of Rwanda and a city of over a million inhabitants. On account of the observed dynamic development, the 'Singapore of Africa' epithet was first applied by The Economist in 2012 [1], and was taken to reflect the rapid development of the services sector and pro-environmental solutions introduced by local authorities. Rwanda offers an example of a very radical policy as regards the fight with plastic. Citizens also participate in unpaid work for the community, comprising, for instance, monthly cleaning of streets [70,71]. Due to this activity, Rwanda's capital has come to be known as 'the cleanest city in Africa' [72]. The term is taken to refer to the country as a whole, as much as to its capital, with references being made to a smart city model, African style. As one aspect of the smart city entails skillfully managed resources of urban greenspace (including areas set aside for agriculture), it is worth comparing and contrasting this capital city in Central Africa with a southeast Asian city it often seems to be compared with. Verification (or otherwise) of this point of view, often repeated in media discourse, in relation to urban agriculture has constituted a key task of the work presented here.

In general terms, a genuine resemblance between Kigali and Singapore-at least at moments-reflects the large share of urban greenspace within the city as well as (first and foremost) a level of cleanliness on the streets that stands out when comparisons are made with other African metropolises. However, a matter of much wider significance is the fact that the Rwandan authorities have for years drawn directly on Singapore's example and 
experience when it comes to spatial planning. Indeed, Lee Kuan Yew, co-founder of the People's Action Party and first long-term Premier of Singapore (1959-1990), spent part of his time in the first decade of the 21st century as an advisor to President of Rwanda, Paul Kagame, in matters of effective governance [73]. What is more, Kigali is an example of an African metropolis in which, similar to Singapore, the assumptions of the smart, sustainable and resilient city concepts are being pursued [74].

It is worth looking at the transformation that Kigali went through, from being a subordinate colonial city to being a model vis-à-vis spatial planning [73,75]. The city was a minor trading center dominated by low-rise, informal housing, with most of the area taken by marginal districts [73]. The situation began to change slowly after 1962, when Kigali became the capital of an independent state. Three decades later, the population had exceeded 200,000. However, the genocide in 1994 led to the city being abandoned, with its infrastructure left devastated. In spite of the marked decline in population that occurred, several years on from the genocide, a major increase in population had already taken place in the capital. Kigali authorities, faced with the explosive population growth typical for so many metropolises in the region, and with the resulting sprawl of an informally built suburb, were not in a position to meet the inhabitants' increasing basic needs. The result was a succession of conflicts over spatial resources [75-77]. In addition, one of the major problems was how to provide the growing population with a sufficient amount of food with most of the farmland being destroyed or abandoned. That is when Kigali's residents started to turn wastelands into cultivated plots. Soon after, urban agriculture was implemented in the city's long-term development strategy.

\subsubsection{Spatial Planning and Urban Agriculture Management}

An important issue influencing the effectiveness of spatial planning is the system of land ownership in Rwanda, which differs from that in Singapore. In the period immediately after the genocide, in the face of returning refugees again settling in Kigali, the city authorities had to deal with the problem of claims for building plots. The inadequate supply and then-dominant system of land distribution were not in a position to meet the needs of a dynamically growing number of urban residents. The population flowing in was forced to purchase land belonging to the state prior to gaining a right to use or right of ownership [78].

This kind of situation prevailed for a decade until 2005, when the Organic Law was introduced [79]. This ensured a possibility for land to be purchased and rights of ownership to be acquired, irrespective of ethnic affinities or gender [79]: Article 4. Moreover, a possibility of 'expropriation due to public interest' was introduced, albeit on the basis of prior compensation at an appropriate level [79]: Article 3. This provision aroused considerable controversy, especially on account of the flexible approach to what are regarded as 'public interest projects' [73]. In turn, the Land Governing Law assumed a need for the purchase of land to be registered in line with the Land Tenure Regularization (LTR) Program [80]. Though, unlike in Singapore, it is not the authorities that are the main landowners, in Rwanda, like in the Asian city state, the whole process is the subject of close scrutiny on the part of state institutions that are, at the same time, the main decisionmakers.

The comparison between Kigali and Singapore may also involve the directions taken by spatial development policy in both. Work on the devising of the Kigali Master Plan 2013 was i.a. a matter for foreign specialists associated with the Singaporean consulting firm Surbana Jurong Private Limited, whose services relate to infrastructure and planning in urban areas, and the drawing up of planning documents for various different cities, including Singapore itself [39]. The same firm took part in work to draw up detailed area plans following the 2007 publication of the earlier Kigali Conceptual Master Plan prepared by the American firm Oz Architects [73]. The Master Plan 2013 introduced zoning, and thus regulated the means of land use, the heights of buildings and permissible densities of population in each area. A further assumption is that people living in hazardous areas will be resettled $[75,81]$, and this may be a serious matter for the most vulnerable groups, with 
such negative socioeconomic consequences as loss of means of upkeep and reduced food security, the severing of social ties, marginalization, or even induced homelessness [82,83]. Resettlements therefore lead to the exclusion of the most vulnerable city residents, which is in contradiction with the concepts of smart, resilient and soft cities that comprise solutions aimed at social inclusion.

As early as 2009, urban agriculture gained incorporation in the Kigali Conceptual Master Plan as an element to a strategy whereby the level of food security of inhabitants of the Rwandan capital was to be raised [84]. According to the cited document, 47,000 ha (or $65 \%$ of the city's administrative area) was to be deemed natural, i.e., subject to safeguarding against regular construction. Within that area, some 3481 ha was designated for urban agriculture. At the same time, a 10-people-per-hectare limit was set on permissible population densities in these areas [84]. The Master Plan 2013 encompasses integrated activity to ensure the retention of agriculture across the city-space, an improvement in its level of efficiency, and a curbing of any negative influences on the natural environment. The document assumes conservation measures on cultivated land adjacent to wetlands in areas where slopes are of less than $15 \%$ as well as restrictions on mechanized intensive agriculture on the steeper slopes. Beyond that, to safeguard against erosion where slopes are of $15-25 \%$, there is an effort to promote agroforestry using slope terracing, while slopes in excess of $25 \%$ should only be used for forestry. Two districts are associated with priority cultivation of certain crops, i.e., maize, vegetables, legumes, fruit, rice and soybeans in the Gasabo District as well as coffee and fruit in the Kicukiro District [39].

The document that in the nearest future will shape the spatial distribution of agricultural activities in Kigali is the Master Plan 2020 [40]. Its provisions are, however, ambiguous. On the one hand, according to the document, the area designated to agriculture is $165 \mathrm{~km}^{2}$, which constitutes $22.7 \%$ of the city's total area. Therefore, the projected share of agricultural land is lower compared to the one presented in the 2013 version of the document, where it amounted to $192.9 \mathrm{~km}^{2}$ and $26.4 \%$, respectively $[39,40]$. Thus, in both Kigali and Singapore, there is a tendency to reduce the area occupied by agriculture. On the other hand, one of the objectives of the latest Kigali Master Plan is the reclamation and conservation of agricultural land as well as the promotion of sustainable production methods that would allow the preservation of high-quality soil. As part of the document, zones of 'Zero Net Loss of Agricultural Areas' are to be designated in the city; horticulture is to be integrated in the urban design; and kitchen gardens as well as rooftop farms are to be promoted. However, unlike in the case of Singapore, the Kigali Master Plan does not include modern production methods, such as hydroponics or aquaponics. The implementation of the above provisions of the document is to be possible thanks to the development of the Urban Agriculture Development Plan, the Urban Agriculture Extension Manual and the Integrated Urban Agriculture Management Plan. Moreover, the document also provides for the organization of a series of awareness-raising trainings on sustainable agricultural techniques aimed at city residents. In contrast to Singapore, in Kigali, there is no institution that can provide financial support, especially in the implementation of innovative agrotechnical solutions.

The Kigali Master Plan provides for integrated measures to protect urban agriculture in some valleys and in areas with a slight slope as part of a strategy of increasing the food security of residents. However, crops from most of the valleys within the city limits are to be moved to the highlands in order to protect naturally valuable wetlands. Therefore, the actions contained in the document indicate the will to preserve agriculture in Kigali's space. It turns out, however, that most of the above protective provisions refer to rural areas within the administrative boundaries of Kigali. In line with the division of the city into different land use zones, agriculture is to be maintained only in rural areas in the northern part of Gasabo and in the south of Nyarugenge. However, the planned share of agriculture in central parts of the city is small. It is to occupy only a limited part of the valleys in the Kicukiro district (south and north of the airport), on the border of densely built-up areas [40]. Taking into account the fact that agriculture is currently present also within the urbanized zone, even in the central districts of the city, it should be expected 
that, in the nearest future, similar to Singapore, large-scale agriculture will be pushed to peripheral areas. However, contrary to the Asian city-state, the planning documents do not include wide-ranging implementation of innovative urban production methods based on modern technologies that could serve as an alternative to traditional agriculture.

In comparison to Singapore, the Kigali authorities adopted a slightly different policy with regard to small, cultivated plots in wastelands. A common practice mentioned in the interview with a representative of the Kigali City Hall is the granting of a temporary right to lease unused plots of land (both state-owned and privately owned land) for the purpose of food production. A sole condition here is that this activity should not be pursued on an industrial scale but should rather serve to meet people's own nutritional needs, albeit with the possibility also envisaged of surplus produce being sold. Nonetheless, when the original owner expresses their will to develop a plot of land, local farmers must change their location. Such a practice allows for the temporary use of wastelands while supporting the local population in improving their food security. As it is based on a grassroots initiative of residents, it also fits into the concepts of sustainable, smart, resilient and soft cities. A similar practice has been used since the 1990s in Havana. In the Cuban capital, however, agricultural activity that was originally intended to be temporary turned out to be long term, as gardens founded almost three decades ago continue to operate today [33,44]. In turn, in Singapore, even though it is possible to obtain a short-term license or land lease for urban agriculture, such permits are rarely issued. In addition, in order to obtain them, residents must meet a number of administrative requirements, and their applications are subject to prior scrutiny by the authorities $[57,58]$.

Another practice that is part of the policy against malnutrition in Kigali is the promotion of the so-called kitchen gardens (Kinyarwanda: akarima k'igikoni). The city authorities support the cultivation of fruit and vegetables for the needs of individual households. The campaign named 'Promoting Diversified Diet and Innovative Urban Farming for a better and Well-Nourished City' implemented in 2017 by the City Hall of Kigali in cooperation with the International Potato Center is one of the examples of actions taken by the city authorities to increase the food security of residents and to enrich and diversify the diet, especially among children. The action involved a series of trainings aimed at educating the population in the field of organic fruit and vegetable cultivation and healthy nutrition. Similar initiatives are not undertaken or even supported by the Singaporean authorities. Urban farms that focus on educational and social activity, if they are not economically viable, are unlikely to survive on the market or to have their lease agreement prolonged.

Based on the abovementioned policy, significant changes in the distribution and characteristics of urban agriculture in Kigali are to be expected in the following decades. It is worth emphasizing that, despite the fact that, as in Singapore, the city authorities are the main decisionmaker in shaping the spatial policy of the Rwandan capital, including the spatial distribution of agricultural areas, the existing institutional and legal framework gives residents a certain degree of agency in this respect. As a result of the possibility of using wastelands for cultivation, urban dwellers have a chance to transform their immediate surroundings in a bottom-up manner in accordance with their needs, even if these changes are only of a short-term nature.

\subsubsection{Contemporary Urban Agriculture in Kigali Spatial Distribution of Urban Agriculture}

The total number of agricultural areas identified with Google Earth tools in Kigali was 780.98 (of total area 1170.4 ha and mean area $11.9 \mathrm{ha}$ ), which were further analyzed during fieldwork. They will be discussed in detail in this article (initially 100 sites were planned to be visited, but due to the limited time of the research and difficult access to two of the selected arable plots, 98 of them were analyzed during fieldwork). The largest number of agricultural sites, 48, is located in the Gasabo district. In the two remaining districts, the number is two times smaller-23 in Kicukiro and 17 in Nyarugenge. In addition, 
5 agricultural areas are located on the border of Nyarugenge and Gasabo districts, 2 on the border of Nyarugenge and Kicukiro, and 3 on the border of Gasabo and Kicukiro.

Features of spatial distribution of urban agriculture in Kigali differ markedly from those in Singapore. First of all, there is no concentration in particular parts of the city, but rather a presence in all districts. Unlike in Singapore, whose relief is not very varied, differences in altitude in Kigali can reach $300 \mathrm{~m}$, and it is largely this factor that determines the distribution of urban agriculture mainly present, where the development of built-up areas is either impossible or very much hindered. The places involved are either extensive and humid valley bottoms between hills, or else the steep slopes of the latter. Among the 98 agricultural sites examined, 35 (of total area 1011.49 ha and mean area 28.9 ha) are located in valleys. Due to high humidity, the use of valley bottoms for development is very difficult and therefore, they are intended for agricultural activities. Often, large areas occupied by agriculture are adjacent to densely built-up residential neighborhoods, occupying the slopes of the valleys. The two contiguous forms of land use create a clear sharp border in space. Otherwise, the vicinity of residential buildings and urban agriculture in the valleys compose a specific rural-urban landscape. It is characteristic of even the most central parts of Kigali (for instance, the area on the border of Nyarugenge and Kicukiro districts). It is worth noting that agricultural areas are adjacent to both densely built-up informal neighborhoods inhabited by the poorest social groups, as well as the formal ones, having a slightly lower building density occupied by the middle and upper-middle classes. The second group of agricultural sites analyzed during fieldwork consists of 63 (of total area 158.89 ha and mean area $2.52 \mathrm{ha}$ ), located on the hill slopes. They usually take the form of small, cultivated plots or vegetable gardens and are situated between residential buildings. They are present in all surveyed districts. Figure 5 presents the distribution of urban agriculture in Kigali, both of the 98 agricultural sites examined during fieldwork and the remaining 682 previously identified in Google Earth.

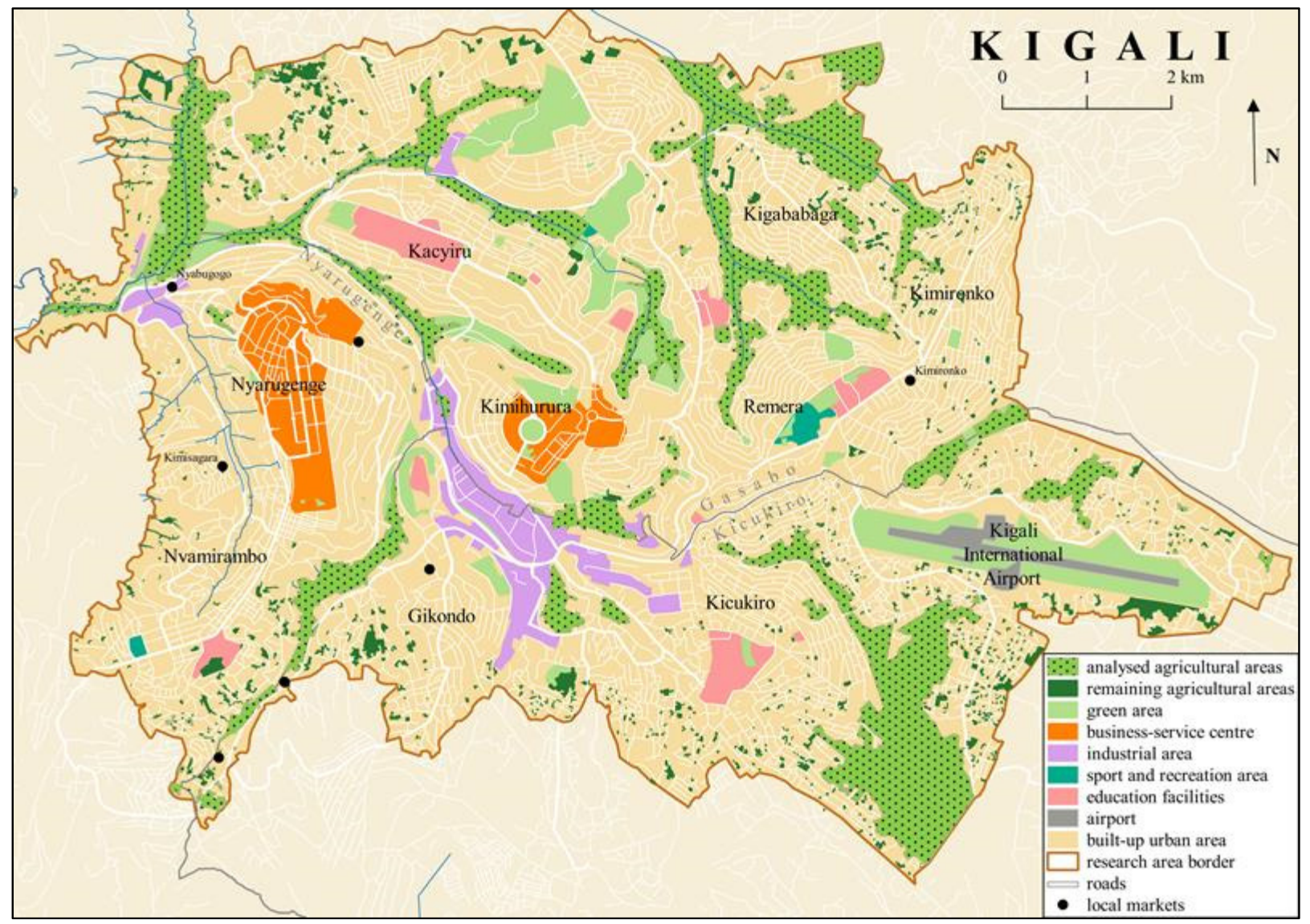

Figure 5. Land use and spatial distribution of urban agriculture in Kigali. 
In the central parts of Kigali, small, cultivated plots on slopes and hilltops are less frequent. The agriculture is concentrated here mainly in vast valley bottoms. This is mainly due to high building density in central sectors. The short distances between buildings limit the possibility for cultivation and setting up vegetable gardens. However, the further away from the center of Kigali, the share of micro-scale agricultural sites located on slopes and hilltops increases significantly. This results from the decline in the building density toward the outskirts of the city. The majority of small, cultivated plots are located on the outer parts of the research area, characterized by the least compact spatial form. In turn, in Singapore, farms of a small total area dominate in the central parts of the city, while large-scale farming is concentrated in the periphery, mainly within the Kranji Countryside.

In Kigali, the spatial distribution of agriculture is, in part, a manifestation of the needs of the capital city's inhabitants. Unlike in Singapore, farming is mainly carried out in the immediate vicinity of residential buildings, sometimes taking the form of the so-called 'kitchen garden' in a person's backyard. What can be regarded as a spatial similarity between Kigali and Singapore is that urban agriculture is present alongside green areas that are highly valuable from the natural point of view. In the case of Singapore, these are the natural wetlands in the Kranji Countryside, while in Kigali, they take the form of wetlands in valley bottoms. In addition, in neither of the cities does agriculture appear commonly in areas in which the services sector or administration hold sway. Hence, the small number of urban farms in Singapore's downtown, and their absence from the summits of the Nyarugenge and Kimihurura heights in Kigali (which, according to spatial planning documents, are to become prestigious service-business centers).

A key practice underpinning the ubiquitous nature of urban agriculture in the city space of Kigali is the transformation of even the smallest wasteland into arable plots. Although this practice is based on a grassroots initiative and enables the participation of residents in the shaping of the city space, it also poses a significant threat. The use of land unsuitable for cultivation, for example, too-steep slopes of hills, leads to the intensification of soil erosion and, consequently, to mass movements hazards. In addition, valuable natural wetlands located in the valley bottoms are also endangered, as they are turned into cultivated plots. The above problems were taken into account in the directions of spatial planning outlined by the Kigali authorities. According to the published master plans from 2009, 2013 and 2020, agriculture, mainly large-scale, is to gradually disappear from the central districts of the city. Additionally, most of the wetlands in the valleys, which are currently occupied by crops, are to be protected as naturally valuable areas where no agricultural activities are planned. The exceptions are agricultural areas in the valleys on the border of the Niboye and Kanombe sectors and the Nyarugunga sector in the Kacukiro district. Moreover, according to the latest 2020 document, agricultural activity is to be restricted in areas with steep slopes (more than $15 \%$ ) in order to prevent soil erosion.

The dynamic in-fill development as well as spatial expansion of the residential neighborhoods are the factors that may significantly contribute to intensified displacement of agriculture from the central districts of the city in the following years. Kigali is an example of a city that, contrary to Singapore, has a relatively high share of wastelands in its space. However, due to the strong economic and political position of Rwanda as well as the increase in the number of foreign investments, gaps in the urban tissue in the central sectors, such as Nyarugenge, Kimihurura, Kacyiru, Kinyinya and Remera, are being filled by buildings. Due to the fact that, so far, these gaps have been occupied by crops and the land use rights granted to inhabitants are short-term in nature, the share of agricultural land in the fastest-growing parts of Kigali will decline. Similar processes took place in Singapore. Urban farms in favorable locations (such as Oh Chin Huat Hydroponic Farms analyzed above) were shut down in order to be replaced by residential neighborhoods.

An example illustrating both the situation of urban agriculture as well as the transformations occurring in Rwandan society is presented in Figure 6a,b. The June 2019 satellite image available in Google Earth clearly points to the plot of 23 ha in the Kinyinya sector in the Gasabo district being under cultivation (Figure 6a). The presence of agriculture in 
this area was also confirmed during fieldwork in July 2019. According to the March 2020 Google Earth image (Figure 6b), the plot was almost completely cleared and was recently turned into a golf course. The area allocated to cultivation was radically reduced to 4.9 ha. Agriculture was only preserved on the edge of the golf course. The fact that farmlands have been replaced by a luxury recreational facility demonstrates the increasing demand for similar leisure activities and may indicate the growing wealth of Rwandan society as well as the influx of foreign tourists and businessmen. The displacement of urban agriculture to the outskirts of the city was observed by M. Taguchi and G. Santini [85]. The authors point out that since the 1990s, when agriculture was included in the Kigali spatial planning policy on the advice of FAO, the city experienced a dynamic development. The Rwandan capital has become one of the fastest growing cities in the world, and agriculture-which was slowly losing its importance, similar to Singaporean urban farms-has begun to be replaced primarily by residential buildings. Our results also attest to what was stated by $\mathrm{S}$. Reuther and N. Dewar [30] with regard to Khayelitsha in Cape Town, that very often land tensions occur between urban agriculture and the development of housing and other uses, such as ecological corridors and public open spaces.

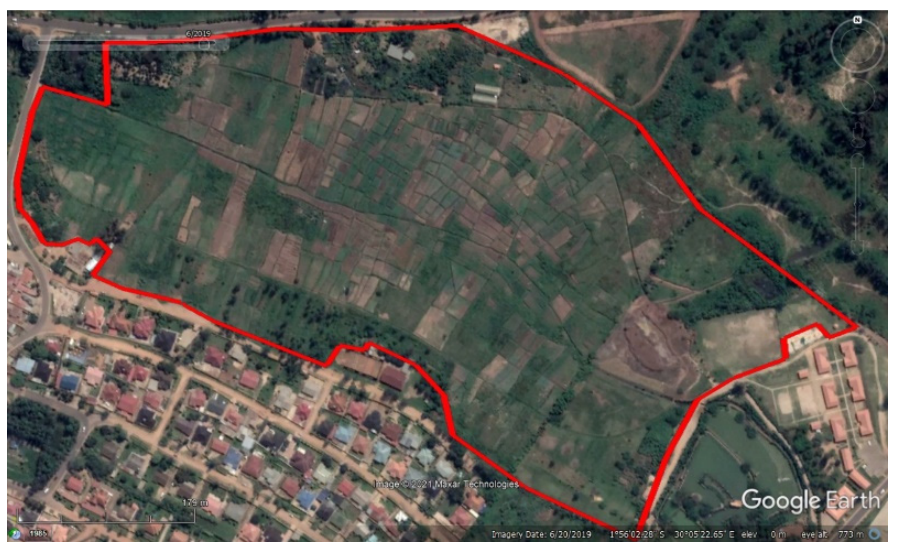

(a)

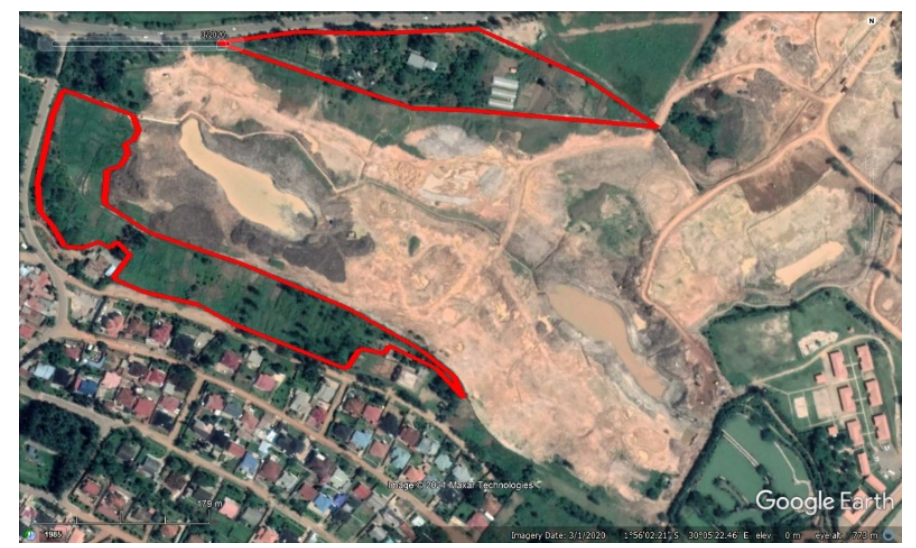

(b)

Figure 6. Area occupied by urban farming (limited by the red outline) in the Kinyinya sector in (a) June 2019; (b) in March 2020 during the construction of the golf course, map data: Google Earth @2021/Maxar Technologies.

\section{Features of Urban Agriculture}

As in Singapore, location exerts an influence on the methods of production used as well as the species of plant cultivated. The valley bottoms are divided into smaller plots that are leased by the city or represent the property of individual farmers (Figure 7a). What are mainly grown here are bananas, maize, and tuberous crops, such as manioc, yams, sweet potatoes, as well as vegetables (e.g., cabbage, lettuce and tomatoes). Particular plots are also used in rice growing, even if this is more typical of suburban areas (Figure $7 \mathrm{~b}$ ). In contrast, on the slopes, the main cultivated species are resistant to the water stress arising due to the low level of the water table. Involved first and foremost is the growing of manioc, sweet potatoes and yams, whereas vegetables are rarely cultivated here. Moreover, bananas and maize are very widespread where slopes are steeper. Taking into account all the studied urban agriculture sites, the dominant crops are maize (68\% of sites analyzed), bananas $(48 \%)$, manioc $(39 \%)$, yams (37\%) and sweet potatoes $(24 \%)$. In all of the agricultural areas visited, plants are grown directly in the ground, and only traditional production methods are applied. Despite the fact that Kigali follows the example of Singapore when it comes to the implementation of ICT, innovative methods of agricultural production are yet to be introduced. 


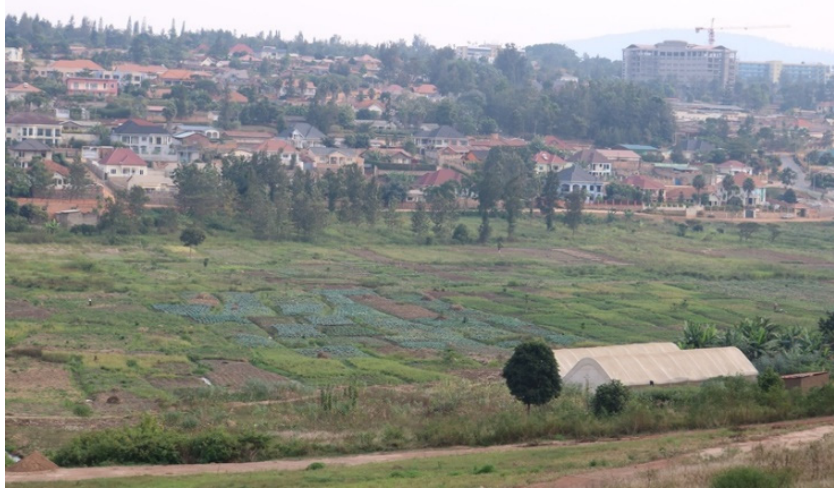

(a)

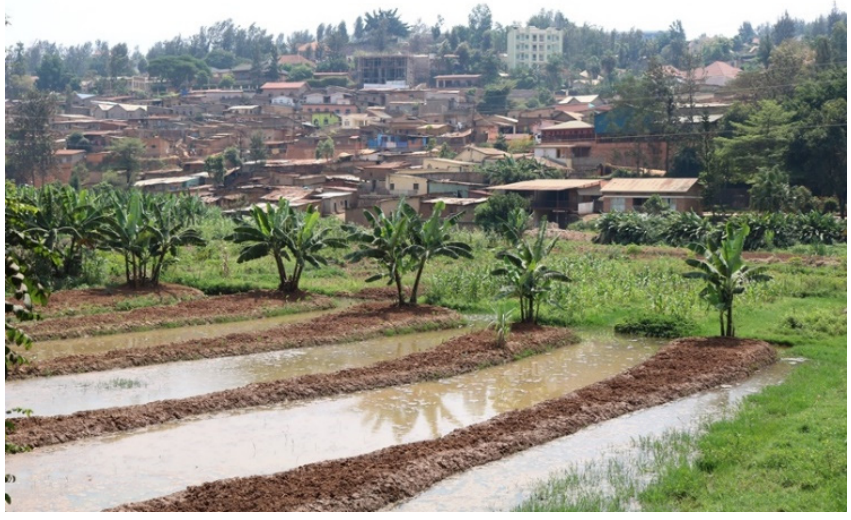

(b)

Figure 7. (a) Valley bottom divided into smaller cultivated plots in the Gasabo district, (b) rice plots in the valley on the border of Gasabo and Nyarugenge districts.

Nevertheless, it is not merely relief, natural conditions or the needs of inhabitants that influence crop cultivation in given areas, as the city authorities are also involved. Fieldwork shows, however, that it is difficult to observe the effects of implementation of provisions concerning the priority of certain crops included in the Kigali Master Plan 2013. There seems, in practice, to be no difference in what crops are being grown in the three districts. While Gasabo does indeed have dominant cultivation of maize, the document refers to (present at 29 sites) manioc also frequently being present (at 20), along with yams (14), bananas (13) or sweet potatoes (11). In Kicukiro-the area slated for coffee and fruit production under the Master Plan 2013 - it is, again, maize that dominates (17 sites), as well as manioc (11), bananas (8) and yams (5). A similar situation applies to the Nyarugenge District. Taking into account the fact that 6 years have passed since the publication of the 2013 version of the Master Plan to the fieldwork conducted, some effects of its implementation can already be expected. According to the document, depending on the district, the species of plants cultivated should be different; in reality, however, fieldwork attested to them are quite similar.

The role of urban agriculture in Kigali differs greatly from that in Singapore. First and foremost, as subsistence agriculture predominates within the city limits, it is primarily aimed at ensuring food security for urban dwellers. Nevertheless, it is worth noting that in the face of the city's current development and the improvement of living standards of its inhabitants, the functions of agriculture are also changing. It is increasingly becoming an activity that provides additional income to those involved. Farmers sell their crops to intermediaries or distribute their products themselves at local markets. Moreover, taking into account the recent initiatives of the Kigali authorities to promote kitchen gardens, agriculture in the city is also expected to play a role in diversifying the inhabitants' diet and popularizing healthy eating.

In Singapore, some farms, in addition to selling food, also provided trips and educational services, which were an important part of their operation. In Kigali, agriculture mainly brings other social benefits, such as an improvement in the economic situation of inhabitants, as well as the inclusion of excluded social groups. However, these benefits are rather indirect and appear, as it were, alongside the basic function, which is food provision.

\section{Discussion}

\subsection{Future of Urban Agriculture in Singapore}

Agriculture in Singapore awaits a series of major changes, not only quantitative, but also spatial, in connection with the closure and/or relocation of certain farms, as well as qualitative (leading to a change of production methods). The policy that Singapore's authorities pursue as regards the smart city concept is a somewhat selective one. It supports 
actions integrating modern technology, while making it difficult for inhabitants to become involved in bottom-up initiatives that are less advanced technologically but do strengthen ties in society and help educate young people of school age, who usually lack contact with rural areas and do not have much idea of how the food goods that they consume every day are actually produced. The government of Singapore, in fact, takes a rather restrictive approach to civic activism, and that does much to limit the development of, say, community gardens [86]. On the other hand, the building of a contented and healthy community is an aspect of the smart, resilient and soft city concepts, and one intended to facilitate coping with the challenges that today's city poses.

Urban farming in Singapore is, thus, at a turning point, where the technocratic vision of an autocratic city of the future is beginning to win against grassroots initiatives as well as tradition, and low-profit forms of agricultural activity are being pushed out of the urban space. Investments in the latest technology and a drastic policy toward ineffective farms are the way of the Singapore's government to reach the goal set in March 2019 of achieving a $30 \%$ level of food self-sufficiency by 2030 , known as 'the 30 by 30 goal' [87]. It comes, however, at the price of the seizure and development of the land previously allocated to traditional agriculture.

\subsection{Future of Urban Agriculture in Kigali}

Considering the fact that subsistence farming predominates in the capital of Rwanda, nutritional needs of the inhabitants constitute an important factor influencing its presence in the urban space. In order to improve the food security of Kigali's urban dwellers, who suffered from severe food shortages, agriculture was included in the city's spatial policy. Currently, however, its role is changing. First of all, given that the vast majority of households in Kigali have achieved food security (according to the Ministry of Agriculture in 2015, only 3\% of urban households in Rwanda's capital were considered food insecure), agriculture is not so much a basis for livelihood as it is an additional source of income for the inhabitants, who sell agricultural produce, thereby improving their financial situation [88]. The fact that agriculture is slowly ceasing to be indispensable to secure livelihoods and provide food for families may work to its disadvantage. Once the food security of the inhabitants is achieved, local food production will no longer be a strategic activity and will be pushed out into peri-urban or rural areas, as demonstrated by the Singapore example. It should be noted, however, that the situation related to food security in the capital of Rwanda is still unstable, as almost $35 \%$ of households within the city are considered marginally food secure [88]. Urban agriculture, although slowly losing its importance, still serves as a kind of safety buffer for residents.

The urban tissue of Kigali is currently undergoing dynamic changes, similar to those that took place in Singapore. They result from the present urban planning policy as well as from increased foreign investment and hence, the inflow of foreign capital. Due to the gradual improvement of residents' economic status, urban farming will most likely become the first victim of the spatial expansion and in-fill development, the first cases of which are presented in this paper. Moreover, the government's policy toward agricultural activity in Kigali is ambiguous. On the one hand, urban agriculture is to be removed from the valleys in order to enable the restoration and protection of valuable natural wetlands. On the other hand, as part of the policy of food security improvement, the authorities allow residents to use wastelands for short-term cultivation.

As urban agriculture is not a highly profitable activity, and Kigali is one of the fastest growing cities in Africa, it is very important to ask not whether, but how long agriculture will be able to remain in the urban space. The Kigali authorities choose similar solutions regarding urban development to those currently being implemented in Singapore. While comparing the two documents-the Singapore Master Plan 2019 and Kigali Master Plan 2020 - there are many noticeable similarities concerning the policy toward urban agriculture in both cities. Agricultural areas are to be concentrated mainly on the outskirts of the cities, and the area that they currently occupy is to be limited in both cases. Thus, will Kigali's 
urban agriculture, like that in Singapore, be gradually pushed out of the most central districts of the city, to finally disappear completely from the urban space? The results of the fieldwork conducted in Kigali lead toward a positive answer to the question posed.

As for the qualitative changes, according to the latest Kigali Master Plan, the priority action is the modernization and mechanization of urban agriculture as well as increasing productivity while reducing the use of artificial fertilizers and pesticides. These provisions regard, primarily, peri-urban areas though, as agriculture is to be removed from inner-parts of the city. As for the integration of modern cultivation methods, the document merely mentions rooftop farming. Nevertheless, considering the fact that Kigali, to a certain degree, follows Singapore's steps, some changes might be anticipated. The transformations projected in the Kigali Master Plan seek an optimization of land use that, at the same time, takes into account the inhabitants' nutritional needs. The limitation of traditional agricultural activity within central parts of the city requires innovative solutions that will sustain the level of food security; therefore, the methods implemented in Singapore, such as hydroponics, aquaponics and rooftop farming, might prove effective enough to catch the authorities' attention.

Table 1 presents a juxtaposition of the research results with regard to 36 farms studied in Singapore and 98 agricultural areas analyzed in Kigali.

Table 1. Research results for Singapore and Kigali.

\begin{tabular}{|c|c|c|c|}
\hline Characteristic & Attribute & Singapore & Kigali \\
\hline \multirow{3}{*}{$\begin{array}{l}\text { institutional and legal } \\
\text { framework of urban } \\
\text { agriculture and policy } \\
\text { towards its development }\end{array}$} & $\begin{array}{c}\text { land ownership and land } \\
\text { use system }\end{array}$ & $\begin{array}{l}90 \% \text { of land state-owned; } \\
\text { the Singapore Land } \\
\text { Authority-the institution } \\
\text { responsible for land management; } \\
\text { land lease for agriculture-a } \\
\text { maximum of } 20 \text { years (extended } \\
\text { from } 10 \text { years); } \\
\text { 1-3 years lease and short-term } \\
\text { farm license system; } \\
\text { limited possibilities to extend the } \\
\text { lease period due to centralized } \\
\text { decision-making process }\end{array}$ & $\begin{array}{l}\text { private ownership of the land } \\
\text { allowed provided every purchase } \\
\text { is registered in line with the Land } \\
\text { Tenure Regularization; common } \\
\text { practice-the granting of a } \\
\text { temporary right to lease unused } \\
\text { plots of land (both state-owned } \\
\text { and privately owned land) for the } \\
\text { purpose of food production } \\
\text { (industrial scale excluded); } \\
\text { centralized } \\
\text { decision-making process }\end{array}$ \\
\hline & $\begin{array}{l}\text { institutions governing } \\
\text { urban agriculture }\end{array}$ & $\begin{array}{c}\text { Agri-Food \& Veterinary Authority } \\
\text { of Singapore (the Singapore Food } \\
\text { Agency; the Animal \& Veterinary } \\
\text { Service) }\end{array}$ & no designated institution \\
\hline & $\begin{array}{l}\text { provisions of the planning } \\
\text { documents }\end{array}$ & $\begin{array}{l}\text { Singapore Master Plan 2019: } \\
\text { planned reduction of the } \\
\text { agricultural area; supported } \\
\text { forms of agricultural activity: } \\
\text { agrotechnology park, aquaculture } \\
\text { farm, plant nursery, hydroponics } \\
\text { farm or agricultural } \\
\text { research/experimental station }\end{array}$ & $\begin{array}{l}\text { Kigali Master Plan } 2020 \text { (and } \\
\text { previous versions from } 2009 \text { and } \\
\text { 2013): planned reduction of the } \\
\text { agricultural land, preservation of } \\
\text { agricultural land in the peri-urban } \\
\text { area; support of kitchen gardens; } \\
\text { planned development of the } \\
\text { Urban Agriculture Development } \\
\text { Plan, the Urban Agriculture } \\
\text { Extension Manual and the } \\
\text { Integrated Urban Agriculture } \\
\text { Management Plan }\end{array}$ \\
\hline
\end{tabular}


Table 1. Cont.

\begin{tabular}{|c|c|c|c|}
\hline Characteristic & Attribute & Singapore & Kigali \\
\hline \multirow[t]{5}{*}{ spatial features } & distribution and location & $\begin{array}{l}\text { main area of concentration of } \\
\text { urban agriculture-the Kranji } \\
\text { Countryside in the periphery of } \\
\text { the city, where } 28 \text { out of } 36(77.8 \%) \\
\text { analyzed urban farms are located, } \\
\text { the remaining } 8 \text { out of } 36(22.2 \%) \\
\text { farms scattered across the } \\
\text { inner-city }\end{array}$ & $\begin{array}{c}\text { concentration in vast valley } \\
\text { bottoms-35 out of } 98(35.7 \%) \\
\text { agricultural sites analyzed; } \\
\text { concentration on hill slopes } 63 \text { out } \\
\text { of } 98 \text { (64.3\%) agricultural sites } \\
\text { analyzed; agriculture present in } \\
\text { all districts: Gasabo (48 sites), } \\
\text { Kicukiro (23), Nyarugenge (17), } \\
\text { Nyarugenge/Gasabo (5), } \\
\text { Nyarugenge/Kicukiro (2), } \\
\text { Gasabo/Kicukiro (3) }\end{array}$ \\
\hline & total area & $\begin{array}{l}188.82 \text { ha (the Kranji } \\
\text { Countryside-178.76 ha; other } \\
\text { districts-10 ha) }\end{array}$ & $\begin{array}{l}1170.4 \text { ha (valley } \\
\text { bottoms-1011.49 ha; hill } \\
\text { slopes-158.89 ha) }\end{array}$ \\
\hline & mean area & $\begin{array}{c}5.24 \text { ha (the Kranji } \\
\text { Countryside-6.39 ha; other } \\
\text { districts }-1.25 \text { ha) }\end{array}$ & $\begin{array}{c}11.9 \text { ha (valley bottoms - 28.9 ha; } \\
\text { hill slopes }-2.52 \text { ha) }\end{array}$ \\
\hline & minimum area & 0.28 ha & 0.009 ha \\
\hline & maximum area & 21 ha & 284.59 ha \\
\hline \multirow{4}{*}{ inherent features } & systems of production & $\begin{array}{c}28 \text { farms }(77.8 \%) \text { _plant } \\
\text { production; } 6 \text { farms } \\
(16.7 \%) \text {-animal production; } 2 \\
\text { farms }(5.5 \%) \text { - plant and animal } \\
\text { production (aquaculture } \\
\text { included) }\end{array}$ & $\begin{array}{l}96 \text { urban agriculture sites } \\
(98 \%) \text { - plant production; } 2 \text { sites } \\
(2 \%) \text { - plant and animal } \\
\text { production }\end{array}$ \\
\hline & main crops & $\begin{array}{l}\text { Asian leafy vegetables-21 farms } \\
(58.3 \% \text { of all farms analyzed and } \\
70 \% \text { of farms specialized in plant } \\
\text { production) }\end{array}$ & $\begin{array}{c}\text { maize }(68 \% \text { of sites analyzed), } \\
\text { bananas }(48 \%) \text {, manioc }(39 \%), \\
\text { yams }(37 \%) \text { and sweet potatoes } \\
(24 \%), \text { other crops: cabbage, } \\
\text { lettuce, tomatoes, rice }\end{array}$ \\
\hline & main production methods & $\begin{array}{l}14 \text { farms }(38.9 \%) \text { _soil-based } \\
\text { cultivation; } 7 \text { farms } \\
(19.4 \%) \text {-hydroponics; other } \\
\text { methods-organoponics, } \\
\text { grow-bags }\end{array}$ & $\begin{array}{l}\text { soil-based cultivation, only } \\
\text { traditional production methods }\end{array}$ \\
\hline & functions & $\begin{array}{l}\text { primary: commercial; secondary: } \\
\text { recreational, educational }\end{array}$ & $\begin{array}{l}\text { primary: subsistence, secondary: } \\
\text { commercial (sale of surpluses) }\end{array}$ \\
\hline
\end{tabular}

The two cities studied provide two distinct examples of how urban agriculture can develop and what forms it can take under different socio-economic, political and cultural conditions. The attributes of urban agriculture in both cases differ in terms of spatial and inherent features, as well as the scope of grassroots initiatives and inhabitants' agency in shaping urban space. Nevertheless, the analysis of the institutional and legal framework of urban agriculture and the policy toward its development proved that certain similar patterns may be observed. This mainly includes the planned reduction of farmland contained in the analyzed planning documents, as well as the process of large-scale urban agriculture being pushed out into the periphery of both cities. It should be noted, however, that in the case of Singapore, the alternative to limiting agricultural areas proposed by the authorities is the implementation of innovative production methods based on high technologies, while in Kigali such solutions have not been promoted so far, although they could prove to be an effective and sustainable solution to the problems with food security of the inhabitants. 


\section{Conclusions}

The above case studies involving Singapore and Kigali offer two examples of cities in which urban agriculture differs markedly from the point of view of methods of production used and the role played in the spatial and functional structure. This reflects both the natural, socioeconomic and political context and the institutional and legal structures that are in place. A matter of significance for the latter is the scale of the presence of agriculture in the cities selected on which the nature of management is dependent. In the case of Singapore, this is currently, in fact, a marginal activity that does not represent a policy priority for the authorities, even in the context of the inhabitants' almost total dependence on imports for their food security. In turn, in Kigali, agriculture is an integral element of the city ecosystem, and one whose presence and role is sufficient to ensure consideration being given to it as the development policy in the Rwandan capital is pursued.

For many decades, urban agriculture was regarded by planners and government representatives in many countries as a form of resistance to urban development priorities and was, therefore, prohibited from the urban space [31]. Despite its role in poverty alleviation and food security improvement, there appeared to be little political will to support urban agriculture [89]. Nevertheless, progress is being made, and the attitude toward the activity is gradually changing. In many cities of the world, the legislative restrictions on urban agriculture have been removed and systems designed to support urban agriculture are even put in place [31]. In the case of the two cities analyzed in this paper, urban agriculture is indeed included in the land-use policy. Thus, while it takes into account the planning documents of both Singapore and Kigali (i.e., the Master Plan 2019 in the case of Singapore and the Kigali Master Plan 2013), the vision for the future situation looks quite dissimilar in the two metropolises. Moreover, in the two cases presented, the approaches toward urban agriculture to a different extent comply with the principles of smart, resilient and soft urban development. Certain solutions promoted by the cities decisionmakers might be considered as being in line with the concepts, while others are quite the opposite. In the case of Singapore, the emphasis is on modern agriculture based around high-technology and not occupying the valuable and limited resource that space represents for the city. Its place, therefore, falls within a technocratic vision of the smart city, with inhabitants being encouraged to use modern technology in urban agriculture, while support is not forthcoming for initiatives based around the 'more conventional' community gardens or farms in general cultivating land in a traditional way. Bottom-up initiatives and participation of residents are limited, which is inconsistent with the assumptions of at least two pillars of the smart city concept, which are smart people and smart governance. Neglecting the grassroots and community activities of inhabitants as well as the social function of urban gardens is also inconsistent with the assumptions of the soft city, which is based on simple solutions developed by the citizens themselves. Innovative methods of agricultural production such as hydroponic modules often placed on rooftops or indoors, have several socio-economic benefits, as their presence increases the multifunctionality of the urban space and provides for the shortening of value chains, which falls within the smart, resilient and soft city concepts. At the same time, however, such high-technology production systems have fewer benefits in environmental and ecological terms, as they do not help preserve natural resources or increase the share of green areas. Moreover, the reduction in the agricultural land outlined in the current Singapore Master Plan will lead to a further decrease in the share of green areas within the city limits.

In Kigali, the authorities seek optimal means of using land whose geophysical features preclude it from being built on, yet urban agriculture is to be preserved almost exclusively in peri-urban areas. At the same time, authorities offer inhabitants a certain freedom to make use of unused land in cultivation, in line with their needs. This conferment of a right of initiative among citizens is in line with the smart city concept and its smart governance aspect, as well as the soft city concept, as it gives the inhabitants the possibility to create and shape their own urban space, according to their needs. Moreover, the creation of kitchen gardens and the transformation of small-scale wastelands into cultivated plots 
leads to the improvement of the residents' food security and enhances their ability to cope with stresses, such as a drastic increase in food prices, which is in line with the urban resilience concept. In Singapore, the authorities are more restrictive in these matters, with a large proportion of the farms studied, especially those performing social or community functions, not having their land leases prolonged.

While the two cities do clearly differ significantly where urban agriculture is concerned, it is possible to note certain similarities as well. In the first place, it is worth recalling the system of land ownership, wherein the authorities in both states are the main decisionmakers when it comes to land management. While in Rwanda (unlike Singapore), they are not actually the main owners, Article 13 of the Organic Law confers very broad powers with regard to control over economic activity in general within the city. In neither case is it possible to regard urban agriculture as a priority activity. Though the issue appears in planning documents, with reference made to the significance from the point of view of inhabitants' food security and wellbeing, the activity is not important enough for the space of economic significance to be allocated. So, while the scale of urban agriculture in Kigali is incomparably greater than in Singapore, even here, the activity only takes in those areas incapable of being used in construction. Singapore simply has a smaller share of this kind of area unsuited to being built up. Furthermore, the fact that Rwanda is developing dynamically at present suggests that upcoming decades will see demands for land resources increase, just as it did in Singapore, which is, after all, a model for the Rwandan authorities. This should ensure urban agriculture's expulsion from whichever areas are capable of supporting more profitable types of economic activity. It remains in question whether the Kigali's authorities will further follow Singapore's footsteps and start supporting high-tech initiatives, enabling the efficient use of scarce land resources. As innovative methods of agricultural production are indeed gaining in importance in fast developing cities of the Global South, they may also prove effective and beneficial in the capital of Rwanda. Nevertheless, it is important to emphasize that, in contrast to Singapore, whose experience is quite consolidated, in Kigali, the policy agenda as well as the approach to managing urban agriculture might still evolve in a different direction. As Kigali's urban tissue is currently under dynamic transformation, solutions integrating urban agriculture into urban space planning can still be introduced. By combining innovative solutions with the grassroots initiatives of the inhabitants, Kigali could create sustainable urban food systems, while achieving a high level of urban resilience.

Author Contributions: Conceptualization, A.G. and K.G.; methodology, A.G.; validation, A.G., K.G.; formal analysis, A.G.; investigation, A.G. and K.G.; resources, A.G.; writing-original draft preparation, A.G.; writing-review and editing, A.G. and K.G.; visualization, A.G. and K.G; project administration, A.G.; funding acquisition, A.G. Both authors have read and agreed to the published version of the manuscript.

Funding: This research was funded by the Faculty of Geography and Regional Studies of the University of Warsaw (SOP-87/19; SOP-130/19; SOP-38/2020; SWIB 36/2021) and Rada Konsultacyjna ds. SRN of the University of Warsaw (20/II/2019).

Conflicts of Interest: The authors declare no conflict of interest.

\section{References}

1. The Economist. Africa's Singapore? Available online: https://www.economist.com/business/2012/02/25/africas-singapore (accessed on 10 July 2021).

2. Foreign Policy. Africa's Singapore Dream. Available online: https://foreignpolicy.com/2015/04/02/africas-singapore-dreamrwanda-kagame-lee-kuan-yew / (accessed on 10 July 2021).

3. EJinsight. Rwanda: From Genocide to "Africa's Singapore". Available online: https://www.ejinsight.com/eji/article/id/210842 7/20190411rwanda-from-genocide-to-africas-singapore (accessed on 10 July 2021).

4. Foreign Brief. Geopolitical Risk Analysis. Kagame and Kigali: Rwanda's Curious Rise to Africa's Envy. Available online: https:/ / www.foreignbrief.com/africa/kagame-and-kigali-rwandas-curious-rise-to-africas-envy/ (accessed on 10 July 2021).

5. Polemics. The Magazine of Diplomatic Academy of Vienna. The Singapore of Africa? Available online: https://www.polemicsmagazine.com/econ/rwanda-economic-miracle (accessed on 10 July 2021). 
6. De Zeeuw, H.; Van Veenhuizen, R.; Dubbeling, M. The role of urban agriculture in building resilient cities in developing countries. J. Agric. Sci. 2011, 149, 153-163. [CrossRef]

7. Pearson, L.J.; Pearson, L.; Pearson, C.J. Sustainable urban agriculture: Stocktake and opportunities. Int. J. Agric. Sustain. 2010, 8, 7-19. [CrossRef]

8. Ferreira, A.J.D.; Guilherme, R.I.M.M.; Ferreira, C.S.S. Urban agriculture, a tool towards more resilient urban communities? Curr. Opin. Environ. Sci. Health 2018, 5, 93-97. [CrossRef]

9. Gulyas, B.Z.; Edmondson, J.L. Increasing city resilience through urban agriculture: Challenges and solutions in the Global North. Sustainability 2021, 13, 1465. [CrossRef]

10. Langemeyer, J.; Madrid-Lopez, C.; Beltran, A.M.; Mendez, G.V. Urban agriculture-A necessary pathway towards urban resilience and global sustainability? Landsc. Urban Plan. 2021, 210, 104055. [CrossRef]

11. Górna, A. Urban agriculture: An opportunity for sustainable development. In Globalización y Desarollo Sostenible; Czerny, M., Serna Mendoza, C.A., Eds.; Wydawnictwa Uniwersytetu Warszawskiego: Warszawa, Poland, 2018; pp. 129-142. [CrossRef]

12. Albino, V.; Berardi, U.; Dangelico, R.M. Smart cities: Definitions, dimensions, performance, and initiatives. J. Urban Technol. 2015, 22, 3-21. [CrossRef]

13. Monfaredzadeh, T.; Berardi, U. Beneath the smart city: Dichotomy between sustainability and competitiveness. Int. J. Sustain. Build. Technol. Urban Dev. 2015, 6, 140-156. [CrossRef]

14. Maye, D. "Smart food city": Conceptual relations between smart city planning, urban food systems and innovation theory. City Cult. Soc. 2019, 16, 18-24. [CrossRef]

15. Chelleri, L. From the «Resilient City» to Urban Resilience. A review essay on understanding and integrating the resilience perspective for urban systems. Doc. D'anàlisi Geogràfica 2012, 58, 287-306. [CrossRef]

16. Jabareen, Y. Planning the resilient city: Concepts and strategies for coping with climate change and environmental risk. Cities 2013, 31, 220-229. [CrossRef]

17. Sim, D. Soft City: Building Density for Everyday Life; Island Press: Washington, DC, USA, 2019.

18. Mougeot, L.J. Urban Agriculture: Definition, Presence, Potentials and Risks, and Policy Challenges; Cities Feeding People Series; IDRC: Ottawa, ON, Canada, 2000.

19. Bryld, E. Potentials, problems, and policy implications for urban agriculture in developing countries. Agric. Hum. Values 2003, 20, 79-86. [CrossRef]

20. De Bon, H.; Parrot, L.; Moustier, P. Sustainable urban agriculture in developing countries. A review. Agron. Sustain. Dev. 2010, 30, 21-32. [CrossRef]

21. Aubry, C.; Ramamonjisoa, J.; Dabat, M.H.; Rakotoarisoa, J.; Rakotondraibe, J.; Rabeharisoa, L. Urban agriculture and land use in cities: An approach with the multi-functionality and sustainability concepts in the case of Antananarivo (Madagascar). Land Use Policy 2012, 29, 429-439. [CrossRef]

22. Giradet, H. Urban agriculture and sustainable urban development. In Continuous Productive Urban Landscapes, 1st ed.; Viljoen, A., Howe, J., Eds.; Elsevier: Oxford, UK, 2005; pp. 32-39.

23. Ola, A. Building a food-resilient city through urban agriculture: The case of Ilorin, Nigeria. Town Reg. Plan. 2020, 77, 89-102.

24. Gyasi, E.A.; Fosu, M.; Kranjac-Berisavljevic, G.; Mensah, A.M.; Obeng, F.; Yiran, G.A.B.; Fuseini, I. Building Urban Resilience Assessing Urban and Peri-Urban Agriculture in Tamale, Ghana; United Nations Environment Programme (UNEP): Nairobi, Kenya, 2014; ISBN 978-92-807-3372-3.

25. Le, H.T.; Vo, T.H.L.; Chau, N.H. The role of urban agriculture for a resilient city. J. Vietnam. Environ. 2020, 12, 148-154. [CrossRef]

26. Padgham, J.; Jabbour, J.; Dietrich, K. Managing change and building resilience: A multi-stressor analysis of urban and peri-urban agriculture in Africa and Asia. Urban Clim. 2015, 12, 183-204. [CrossRef]

27. Smit, J.; Nasr, J.; Ratta, A. Urban Agriculture: Food, Jobs and Sustainable Cities; United Nations Development Programme: New York, NY, USA, 1996; ISBN 978-9-21126-047-2.

28. Chaudhuri, N. Using Participatory Education and Action Research for Health Risk Reduction Amongst Farmers in Dakar, Senegal. Available online: https:/ / www.taylorfrancis.com/chapters/edit/10.4324/9781849770439-34/using-participatory-educationaction-research-health-risk-reduction-amongst-farmers-dakar-senegal-nita-chaudhuri (accessed on 10 July 2021).

29. Maldonado Villavicencio, L. Urban Agriculture as a Livelihood Strategy in Lima, Peru. Available online: https:// www.taylorfrancis.com/chapters/edit/10.4324/9781849770439-11/urban-agriculture-livelihood-strategy-lima-peru-luismaldonado-villavicencio (accessed on 10 July 2021).

30. Reuther, S.; Dewar, N. Competition for the use of public open space in low-income urban areas: The economic potential of urban gardening in Khayelitsha, Cape Town. Dev. S. Afr. 2006, 23, 97-122. [CrossRef]

31. Redwood, M. Agriculture in Urban Planning Generating Livelihoods and Food Security; IRDC: Ottawa, ON, Canada, 2009; pp. 1-20. ISBN 978-1-84407-668-0.

32. Chaplowe, S.G. Havana's popular gardens: Sustainable prospects for urban agriculture. Environmentalist 1998, 18, 47-57. [CrossRef]

33. Altieri, M.A.; Companioni, N.; Cañizares, K.; Murphy, C.; Rosset, P.; Bourque, M.; Nicholls, C.I. The greening of the "barrios": Urban agriculture for food security in Cuba. Agric. Hum. Values 1999, 16, 131-140. [CrossRef]

34. Koont, S. The urban agriculture of Havana. Mon. Rev. 2009, 60, 44. [CrossRef] 
35. Bopda, A.P.; Awono, L. Institutional development of urban agriculture-an ongoing history of Yaoundé. In African Urban Harvest; Prain, G., Karanja, N., See-Smith, D., Eds.; Springer: New York, NY, USA, 2010; pp. 71-94.

36. Nasinyama, G.W.; Cole, D.C.; Lee-Smith, D. Health impact assessment of urban agriculture in Kampala. In African Urban Harvest; Prain, G., Karanja, N., See-Smith, D., Eds.; Springer: New York, NY, USA, 2010; pp. 167-190.

37. Diehl, J.A.; Sweeney, E.; Wong, B.; Sia, C.S.; Yao, H.; Prabhudesai, M. Feeding cities: Singapore's approach to land use planning for urban agriculture. Glob. Food Secur. 2020, 26, 100377. [CrossRef]

38. Government of Singapore. The Planning Act Master Plan Written Statement, 2019. Available online: https://www.ura.gov.sg/ Corporate/Planning/Master-Plan (accessed on 31 January 2021).

39. City of Kigali. Kigali City Master Plan Report. Available online: https:/ / kigalicity.gov.rw/fileadmin/templates/Documents/ reports/KIF_29.01.2014_Master_Plan_Presentation.pdf (accessed on 10 July 2021).

40. City of Kigali. Kigali Master Plan 2050. Master Plan Report. Available online: https://bpmis.gov.rw/asset_uplds/kigali_master_ plan/1_Kigali\%20Master\%20Plan_Analysis\%20\&\%20VisionLowRes.pdf (accessed on 10 July 2021).

41. Forster, D.; Buehler, Y.; Kellenberger, T. Mapping urban and peri-urban agriculture using high spatial resolution satellite data. J. Appl. Remote Sens. 2009, 3, 033523. [CrossRef]

42. Drechsel, P.; Dongus, S. Dynamics and sustainability of urban agriculture: Examples from sub-Saharan Africa. Sustain. Sci. 2010, 5, 69-78. [CrossRef]

43. Taylor, J.R.; Lovell, S.T. Mapping public and private spaces of urban agriculture in Chicago through the analysis of high-resolution aerial images in Google Earth. Landsc. Urban Plan. 2012, 108, 57-70. [CrossRef]

44. Górna, A.; Górny, K. Urban agriculture in Havana-evidence from empirical research. Misc. Geogr. 2020, 24, 85-93. [CrossRef]

45. IMD. Smart City Index 2019. Available online: https://www.imd.org/research-knowledge/reports/imd-smart-city-index-2019/ (accessed on 31 January 2021).

46. Woo, J.J. Singapore's Smart Nation Initiative-A Policy and Organisational Perspective; Lee Kuan Yew School of Public Policy, National University of Singapore: Singapore, 2017; Available online: http:/ / www.smartnation.sg/initiatives/ (accessed on 31 January 2021).

47. Ho, E. Smart subjects for a Smart Nation? Governing (smart) mentalities in Singapore. Urban Stud. 2017, 54, 3101-3118. [CrossRef]

48. Kong, L.; Yeoh, B.S. Social constructions of nature in urban Singapore. Jpn. J. Southeast Asian Stud. 1996, 34, 402-423. [CrossRef]

49. Tan, K.W. A greenway network for Singapore. Landsc. Urban Plan. 2006, 76, 45-66. [CrossRef]

50. Newman, P. Biophilic urbanism: A case study on Singapore. Aust. Plan. 2014, 51, 47-65. [CrossRef]

51. Tan, P.Y.; Wang, J.; Sia, A. Perspectives on five decades of the urban greening of Singapore. Cities 2013, 32, 24-32. [CrossRef]

52. Roth, M.; Chow, W.T. A historical review and assessment of urban heat island research in Singapore. Singap. J. Trop. Geogr. 2012, 33, 381-397. [CrossRef]

53. Tey, Y.S.; Suryani, D.; Emmy, F.A.; Illisriyani, I. Food consumption and expenditures in Singapore: Implications to Malaysia's agricultural exports. Int. Food Res. J. 2009, 16, 119-126.

54. Shatkin, G. Reinterpreting the Meaning of the 'Singapore Model': State Capitalism and Urban Planning. Int. J. Urban Reg. Res. 2009, 38, 116-137. [CrossRef]

55. Haila, A. Urban Land Rent: Singapore as a Property State; John Wiley \& Sons: Chichester, UK, 2016; ISBN 978-1-118-82767-3.

56. Han, S.S. Global city making in Singapore: A real estate perspective. Prog. Plan. 2005, 2, 69-175. [CrossRef]

57. Singapore Food Agency. Available online: https://www.sfa.gov.sg/ava (accessed on 31 January 2021).

58. Singapore Land Authority (2020). Available online: https://www.sla.gov.sg/state-land-n-property/land-sales-and-leasemanagement/lease-management/lease-policy (accessed on 31 January 2021).

59. Singapore Food Agency. Available online: https:/ /www.sfa.gov.sg/food-farming/food-farms/starting-a-farm (accessed on 31 January 2021).

60. Dairy Reporter. Available online: https://www.dairyreporter.com/Article/2019/03/27/Singapore-farmers-hope-governmentgives-clarity-on-the-future-of-their-lands (accessed on 10 July 2021).

61. Astee, L.Y.; Kishnani, N.T. Building integrated agriculture: Utilising rooftops for sustainable food crop cultivation in Singapore. J. Green Build. 2010, 5, 105-113. [CrossRef]

62. Liu, T.; Yang, M.; Han, Z.; Ow, D.W. Rooftop production of leafy vegetables can be profitable and less contaminated than farm-grown vegetables. Agron. Sustain. Dev. 2016, 36, 1-9. [CrossRef]

63. Su, Y.L.; Wang, Y.F.; Ow, D.W. Increasing effectiveness of urban rooftop farming through reflector-assisted double-layer hydroponic production. Urban For. Urban Green. 2020, 54, 126766. [CrossRef]

64. Hui, S.C.M. Green Roof Urban Farming for Buildings in High-Density Urban Cities. In Proceedings of the Hainan China World Green Roof Conference, Hainan, China, 18-21 March 2011; pp. 1-9.

65. Wang, T.; Pryor, M. Social Value of Urban Rooftop Farming: A Hong Kong Case Study. In Agricultural Economics-Current Issues; Kulshreshtha, S.N., Ed.; IntechOpen: London, UK, 2019. [CrossRef]

66. Hashim, N.H.; Mohd Hussain, N.H.; Ismail, A. The Rise of Rooftop Urban Farming at George Town, Penang. Environ. Behav. Proc. J. 2018, 3, 351-355. [CrossRef]

67. Orsini, F.; Gasperi, D.; Marchetti, L.; Piovene, C.; Draghetti, S.; Ramazzotti, S.; Gianquinto, G. Exploring the production capacity of rooftop gardens (RTGs) in urban agriculture: The potential impact on food and nutrition security, biodiversity and other ecosystem services in the city of Bologna. Food Secur. 2014, 6, 781-792. [CrossRef] 
68. Safayet, M.; Arefin, M.F.; Hasan, M.M.U. Present practice and future prospect of rooftop farming in Dhaka city: A step towards urban sustainability. J. Urban Manag. 2017, 6, 56-65. [CrossRef]

69. Henderson, J.C. Agro-tourism in unlikely destinations: A study of Singapore. Manag. Leis. 2009, 14, 258-268. [CrossRef]

70. Uwimbabazi, P.; Lawrence, R. Indigenous Practice, Power and Social Control: The Paradox of the Practice of Umuganda in Rwanda. Altern. J. 2013, 20, 248-272.

71. Hasselskog, M.; Schierenbeck, I. National policy in local practice: The case of Rwanda. Third World Q. 2015, 36, 950-966. [CrossRef]

72. Cleanest City in Africa? Kigali Scrubs up, Reuters. Available online: https://www.reuters.com/article/us-rwanda-greenpollution/cleanest-city-in-africa-kigali-scrubs-up-idUSKBN1HR2F8 (accessed on 10 July 2021).

73. Goodfellow, T. Rwanda's political settlement and the urban transition: Expropriation, construction and taxation in Kigali. J. East. Afr. Stud. 2014, 8, 311-329. [CrossRef]

74. Masłon-Oracz, A.; Mazurewicz, M. Smart Regions and Cities Supporting Cluster Development and Industrial Competitiveness in The European Union. Africa's Smart Region Development Influencing Global Competitiveness. In Facing the Challenges in the European Union; Latoszek, E., Proczek, M., Kłos, A., Pachocka, M., Osuch-Rak, E., Eds.; PECSA: Warsaw, Poland, 2015; pp. 335-345.

75. Goodfellow, T.; Smith, A. From urban catastrophe to 'model' city? Politics, security and development in post-conflict Kigali. Urban Stud. 2013, 50, 3185-3202. [CrossRef]

76. Musahara, H.; Huggins, C. Land reform, land scarcity and post-conflict reconstruction: A case study of Rwanda. Eco-Conflicts 2004, 3, 1-4.

77. Manirakiza, V. Promoting inclusive approaches to address urbanisation challenges in Kigali. Afr. Rev. Econ. Financ. 2014, 6, 161-180.

78. Bizimana, J.P.; Mugiraneza, T.; Twarabamenye, E.; Mukeshimana, M.R. Land Tenure Security in Informal Settlements of Kigali City. Case study in Muhima Sector. Rwanda J. 2012, 25, 86-100. [CrossRef]

79. Organic Law $N^{\circ} 08 / 2005$ of 14/07/2005 Determining the Use and Management of Land in Rwanda. Available online: https: / / repositories.lib.utexas.edu/bitstream/handle/2152/4960/4063.pdf;sequence=1 (accessed on 1 May 2021).

80. Law N ${ }^{\circ}$ 43/2013 of 16/06/2013 Governing Land in Rwanda. Available online: http://gmo.gov.rw/fileadmin/user_upload/ laws\%20and\%20policies/Law_N43-2013_of_16-06-2013_governing_land_in_Rwanda.pdf (accessed on 1 May 2021).

81. Baffoe, G.; Malonza, J.; Manirakiza, V.; Mugabe, L. Understanding the concept of neighbourhood in Kigali City, Rwanda. Sustainability 2020, 12, 1555. [CrossRef]

82. Nikuze, A.; Sliuzas, R.; Flacke, J. Towards Equitable Urban Residential Resettlement in Kigali, Rwanda. In GIS in Sustainable Urban Planning and Management; van Maarseveen, M., Martinez, J., Flacke, J., Eds.; CRC Press: Boca Ranton, FL, USA, 2018; pp. 325-344. [CrossRef]

83. Nikuze, A.; Sliuzas, R.; Flacke, J. From Closed to Claimed Spaces for Participation: Contestation in Urban Redevelopment Induced-Displacements and Resettlement in Kigali, Rwanda. Land 2020, 9, 212. [CrossRef]

84. De Kigali, V. Stratégie d'Appui à l'Agriculture Urbaine et Peri-Urbaine de la Ville de Kigali 2009-2012. Rapport Final; FAO: Kigali, Rwanda, 2009.

85. Taguchi, M.; Santini, G. Urban agriculture in the Global North \& South: A perspective from FAO. Field Actions Science Reports. J. Field Actions 2019, 20, 12-17.

86. Tan, L.H.; Neo, H. “Community in Bloom”: Local participation of community gardens in urban Singapore. Local Environ. 2009, 14, 529-539. [CrossRef]

87. Singapore Food Agency. Available online: https://www.sfa.gov.sg/food-farming (accessed on 31 January 2021).

88. Rwanda 2015. Comprehensive Food Security and Vulnerability Analysis. Available online: https://documents.wfp.org/stellent/ groups/public/documents/ena/wfp284395.pdf (accessed on 10 July 2021).

89. Sonneveld, B.G.J.S.; Houessou, M.D.; van den Boom, G.J.M.; Aoudji, A. Where Do I Allocate My Urban Allotment Gardens? Development of a Site Selection Tool for Three Cities in Benin. Land 2021, 10, 318. [CrossRef] 